\title{
0 wybranych przestrzeniach mieszkalnych funkcjonujących współcześnie w miejskim krajobrazie kulturowym
}

\section{On selected living spaces that function in contemporary urban culltural landscape}

\begin{abstract}
Streszczenie
Autorzy artykułu opisują wybrane przykłady przestrzeni mieszkalnych ukształtowanych i zrealizowanych w XX i XXI wieku a funkcjonujących do obecnych czasów w krajobrazie miast. Starają się wyjaśnić i ocenić odniesienia do filozofii ich budowania i etyki projektowania. Szczególnie zwracają uwagę na procesy manipulacji a zachowania szacunku do natury i otwartych przestrzeni. Zostało to przedstawione na przykładach międzywojennych historycznych osiedli w Łodzi im. Mątwiłła Mireckiego i Werkbundu we Wrocławiu oraz miasta ogrodu Zlin firmy Bata. Fabryka butów Baty zmieniła wygląd całego miasta, które stało się sprawnie funkcjonującą przestrzenią, z precyzyjnie zaprojektowaną architekturą warunkującą każdy aspekt życia. Okres powojennej myśli urbanistycznej przedstawiono na wzorze osiedla Sadów Żoliborskich oraz nowatorskiej idei lat 70-tych na przykładzie konkursu na osiedle Ursynów w Warszawie. Odniesiono się do idei miasta ogrodu i jego odsłony w latach 80-tych poprzez tworzenie zielonych, otwartych osiedli w zabudowie niskiej i dywanowej w ramach zleceń rządowych. Wprawdzie te idee nie były zrealizowane ale pozostawała myśl i pragnienie. Poszanowanie terenów zieleni o zasadniczym znaczeniu dla charakteru miejsca zaprezentowano na przykładzie zespołu domów pasywnych w Konstantynowie Łódzkim czy osiedla Aspern w Wiedniu, sposobu ich procedowania i tworzenia. Zwrócono uwagę na rangę poszanowanie wartości krajobrazowych, wyjaśniono zależności pomiędzy przestrzenią, architekturą a naturą. Podjęto próbę znalezienia priorytetowych o kapitalnym znaczeniu elementów gry przestrzennej dla zachowania wartości nadrzędnych dla środowiska naturalnego i architektury.
\end{abstract}

\section{Abstrakt}

The authors of the article describe selected examples of living spaces shaped and constructed in the 20th and 21st century and functioning to the present day in the city landscape. They try to explain and evaluate references to the building philosophy and design ethics. They pay particular attention to the processes of manipulation and respect for nature and open spaces. It was presented on the examples of the historical interwar housing estates in Łódź Mątwiłł Mirecki and Werkbund in Wrocław and the Zlin garden city by the Bata Company. The Bata Shoe Factory changed the shape of the entire city into a functioning space, with architecture conditioning every aspect of life. The period of post-war urban thought was presented on the model of the Sadów Żoliborskie estate and the innovative idea of the 1970s on the example of the competition for the Ursynów estate in Warsaw. It was based on the idea of a garden city and its presentation in the 1980s by creating green, low open housing estates as part of government commissions. Although these ideas were not realized, the idea, thought and desire remained. The respect for green areas of fundamental importance for the character of the place was presented on the example of the passive house complex in Konstantynów Łódzki or the Aspern estate in Vienna. The importance of respect for landscape values was emphasized, and the relationship between space, architecture and nature was explained. An attempt was made to find the main elements of space, which was of paramount importance for the preservation of values superior to the natural environment and architecture.

Słowa kluczowe: urbanistyka, architektura mieszkaniowa, zrównoważone środowisko, krajobraz kulturowy miasta Key words: urban planning, housing architecture, sustainable environment, cultural landscape of the city

\section{Wstęp}

Jako pracownicy naukowo-dydaktyczni w Instytucie Architektury i Urbanistyki Politechniki Łódzkiej i praktykujący architekci od ponad czterdziestu lat poszukujemy miasta, które ma więcej niż tylko zalety funkcjonalne. Równie ważnym elementem kształtowania jego struktury jest otwarta przestrzeń o charakterze publicznym. To ona decyduje, czy ludzie czują się w swoim mieście jak w domu i czy z tym miastem identyfikują się. Na dobre samopoczucie mieszkańców składa się zatem krajobraz kulturowy miejsca, począwszy od standardu mieszka-

\section{Introduction}

As research and teaching staff at the Institute of Architecture and Town Planning of the Lodz University of Technology and practicing architects, for over forty years we have been looking for a city that has more than just functional advantages. An equally important element of shaping its structure is open space of a public nature. It decides whether or not people feel at home in their city and identify with it. The well-being of the residents is thus influenced by the cultural landscape of the place, ranging from the

*dr hab. inż. arch. Joanna Olenderek. prof. PŁ, Wydział Budownictwa, Architektury i Inżynierii Środowiska, Politechnika Łódzka / Associate Professor Dr. Eng. Arch. Joanna Olenderek, Faculty of Civil Engineering, Architecture and Environmental Engineering, Lodz University of Technology, https://orcid.org/0000-0003-3774-3986, e-mail: joanna.olenderek@p.lodz.pl 
nia, osiedla, komunikacji, charakteru przestrzeni publicznych, dostępności do natury. Niniejszy artykuł jest pierwszym z serii poświęconej badaniom nad strukturą osiedli mieszkaniowych wznoszonych w Europie od okresu międzywojennego do współczesności i ich ewaluacji w zakresie wzajemnych relacji przestrzeni architektonicznych i przyrody. Autorzy dla obiektywnego procesu oceny wartości przykładowych zespołów zabudowy zastosowali następujące elementy ich opisu: okres powstania, idea struktury, układ przestrzenny, wielkość, relacje architektura - przestrzeń - natura - krajobraz kulturowy w czasie powstania i dzisiaj. wpisanie w układ miasta. Istotnym elementem oceny jest fakt degradacji lub akceptacji istnienia zespołu oraz na ile spełnia oczekiwania społeczne i kształtuje dobre relacje. W ramach artykułu umieszczono tabelaryczne zestawienie tych wartości.

\section{Osiedla międzywojenne}

Pierwszy wybrany do oceny zespół miejski o funkcji mieszkalnej to wzniesione na Polesiu Konstantynowskim w Łodzi osiedle imienia Mątwiłła-Mireckiego stanowiące przykład reprezentatywny dla polskiej myśli urbanistycznej okresu międzywojennego. Ówczesny awans administracyjny Łodzi do rangi miasta wojewódzkiego wymagał szerokich działań kreacyjnych nie tylko w obszarze kształtowania przestrzeni o charakterze publicznym. Również niedoinwestowane, ubogie, chaotycznie ukształtowane przestrzenie o charakterze mieszkalnym potrzebowały restrukturyzacji i planowego rozwoju. Otworzył się nowy etap formowania obiektów o przeznaczeniu mieszkalnym. W pierwszych latach okresu międzywojennego niemalże zamarło budownictwo kamienic czynszowych, a ożywienie w latach 30. XX w. przyniosło odmienne formy, zmienił się bowiem model standardowy mieszkania. W wyniku zmiany sytuacji w przemyśle włókienniczym, nie wznoszono już przyfabrycznych domów robotniczych i rezydencji przemysłowców. Pojawiła się natomiast potrzeba zapewnienia lokali mieszkalnych dla wzrastającej rzeszy urzędników państwowych i miejskich, funkcjonariuszy wojskowych, przedstawicieli wolnych zawodów, nauczycieli, jak również dla rozgęszczenia i poprawy bytu rodzin robotniczych, żyjących często w złych warunkach. Wychodząc naprzeciw temu zapotrzebowaniu Zarząd Miasta Łodzi podjął w 1928 roku uchwałę o budowie dwóch wielkich kolonii mieszkalnych. Na projekty obu kolonii ogłoszono konkurs. Jedną z nich zamierzano zlokalizować w południowej części miasta w dzielnicy Nowe Rokicie. Dla drugiej obrano teren o wielkości 15 ha, położony w zachodniej części miasta, w dzielnicy Polesie Konstantynowskie, w bezpośrednim sąsiedztwie Parku Ludowego. Po ogłoszeniu wyników konkursu Magistrat, opierając się na orzeczeniu sądu konkursowego, który stwierdził, że żaden z projektów nie może być zrealizowany bez wprowadzenia zmian, zlecił wykonanie dokumentacji kolonii na Polesiu Konstantynowskim, która miała być wzniesiona w pierwszej kolejności, laureatom drugiej i trzeciej nagrody. Nowo opracowany projekt, efekt współpracy czteroosobowego kolektywu (Jerzy Berliner, Jan Łukasik, Miruta Słońska, Witold Szereszewski) zaprezentowano obok projektów Warszawskiej standard of the apartment, housing estate, transport, character of public spaces, access to nature. This article is the first in a series devoted to research on the structure of housing estates built in Europe from the interwar period to the present day and the evaluation in the field of mutual relations between architectural spaces and nature. For the objective process of assessing the value of exemplary building complexes, the authors used the following elements of their description: the period of origin, the idea of the structure, spatial arrangement, size, relations architecture - space - nature - cultural landscape at the time of creation and today, integrated into the city layout. An important element of the assessment is the fact of degradation or acceptance of the existence of the complex and to what extent it meets social expectations and creates good relations. The article provides a table of these values.

\section{Interwar housing estates}

The first urban complex with a residential function selected for the assessment was the Mątwiłł-Mirecki housing estate in Polesie Konstantynowskie in Łódź, constituting an example representative of Polish urban thought of the interwar period. The administrative promotion of Łódź to the rank of the province capital city required extensive creative activities, not only in the area of shaping public space. Underinvested, poor and chaotically shaped residential spaces needed restructuring and planned development as well. A new stage in the formation of residential buildings has opened. In the first years of the interwar period, the construction of tenement houses almost died out, and the revival in the 1930s resulted in different forms, as the standard model of an apartment changed. As a result of the changed situation in the textile industry, factory worker houses and industrialist residences were no longer erected. On the other hand, there was a need to provide housing for the growing number of state and city officials, military functionaries, representatives of the liberal professions, teachers, as well as for the expansion and improvement of the well-being of working class families, often living in poor conditions. In order to meet this demand, the Board of the City of Łódź adopted in 1928 a resolution to build two large residential colonies. A competition was announced. One was to be located in the southern part of the city in the Nowe Rokicie district. For the second one, an area of 15 ha was selected, located in the western part of the city, in the Polesie Konstantynowskie district, in the immediate vicinity of the People's Park. After the announcement of the results of the competition, the Magistrate, based on the decision of the jury, which stated that none of the projects can be implemented without changes, commissioned documentation of the colony in Polesie Konstantynowskie. The newly developed project, the result of cooperation between a four-person collective (Jerzy Berliner, Jan Łukasik, Miruta Słońska, Witold Szereszewski), was 
Spółdzielni Mieszkaniowej na Żoliborzu (Barbara i Stanisław Brukalscy, Bruno Zaborowski) i Gdyńskiej Spółdzielni Mieszkaniowej (Romuald Gutt i Józef Jankowski, Adam Paprocki i Juliusz Żakowski) na wystawie towarzyszącej obradom II Międzynarodowego Kongresu Architektury Nowoczesnej we Frankfurcie nad Menem w 1929 roku, a następnie na warszawskiej wystawie „Mieszkanie najmniejsze" w 1930 roku. Przed przystąpieniem do realizacji ambitnego planu budowy Kolonii na Polesiu Konstantynowskim (docelowo 11 tys. izb), władze miejskie dokładnie rozważały problem jej sfinansowania. Występując ze śmiałym programem budowy mieszkań społecznie najpotrzebniejszych wzorowano się na Wiedniu. Nowa architektura mieszkaniowa ówczesnego Wiednia była rezultatem olbrzymiej akcji magistratu, o rozmiarach której świadczą wyniki: w latach 1923-1927 wybudowano 30 tys. mieszkań. Łódź była zależna od władz centralnych, które ociągały się ze zgodą na, uchwaloną przez władze miejskie, pożyczkę amerykańską, aż kryzys gospodarczy przekreślił możliwość jej uzyskania. W świetle powyższych trudności finansowych tym bardziej należy docenić wysiłek władz samorządowych, które w 1928 roku rozpoczęły budowę kolonii na Polesiu Konstantynowskim. Przy realizacji inwestycji, przeprowadzonej w dwóch etapach i trwającej do 1933 roku, zatrudniono przeszło 2000 robotników, zmniejszając tym samym bezrobocie. Przedsięwzięcie nie zostało wprawdzie doprowadzone do końca, ale jego historia i efekty przestrzenne wybudowanej części osiedla, liczącej około 3 tys. izb (927 mieszkań), stanowia znamienna kartę w walce o mieszkanie społecznie najpotrzebniejsze, nie tylko na arenie krajowej ale i europejskiej. Projekt realizacyjny przewidywał ustawienie 33 budynków mieszkalnych różnego typu (klatkowce, galeriowce, obiekty o strukturze mieszanej klatkowo-galeriowej) zgodnie z najnowszymi tendencjami w planowaniu osiedli, odrzucającymi kompozycje symetryczno-blokowe na rzecz układów liniowych, podporządkowanych zasadzie prawidłowego nasłonecznienia mieszkań i przewietrzania dziedzińców. Budowę zrealizowanej części osiedla prowadzono w dwóch etapach. W ramach pierwszego etapu, w latach 1928-30 wzniesiono 8 budynków mieszkalnych, obejmujących I i II serię. Natomiast etap drugi, trwający do 1933 roku, przyniósł 12 następnych, składających się na III i IV serię. W zakresie I serii wzniesiono 3 budynki o strukturze klatkowej zlokalizowane $\mathrm{w}$ rejonie Al. Unii. Seria II obejmowała 5 budynków klatkowych zwróconych południowymi ścianami szczytowymi do ulicy Srebrzyńskiej. Jej kontynuację stanowiło 6 budynków III serii, w tym 5 o strukturze klatkowej - ustawionych analogicznie jak w II serii oraz 1 usytuowany wzdłuż ulicy Srebrzyńskiej, podobnie jak 2 wzniesione w tej serii galeriowce. Ostatnia seria obejmowała 6 budynków powstałych w rejonie wewnątrzosiedlowej ulicy K. Praussa. Składały się na nią 4 klatkowce, 1 galeriowiec oraz budynek o strukturze mieszanej klatkowo-galeriowej. Na tym budowę domów mieszkalnych zakończono. Z wielu planowanych wcześniej obiektów ogólnych zrealizowano jedynie pawilon na pompy projektu Witolda Szereszewskiego. Najbliższe wybudowania były prawdopodobnie pralnia i kąpielisko osiedlowe, dla których sporządzono projekt realizacyjny. Drogą adaptacji 6 mieszkań w parterach budynków wy- presented next to the projects of the Warsaw Housing Cooperative in Żoliborz (Barbara and Stanisław Brukalscy, Bruno Zaborowski) and the Gdynia Housing Cooperative (Romuald Gutt and Józef Jankowski, Adam Paprocki and Juliusz Żakowski) at the exhibition accompanying the II International Congress of Modern Architecture in Frankfurt am Main in 1929, and then at the Warsaw exhibition "The Smallest Apartment" in 1930. Before starting the ambitious plan to build a colony in Polesie Konstantynowskie (ultimately 11,000 rooms), the city authorities carefully considered the problem of financing it. When presenting a bold program of building, the model was based on Vienna. The new residential architecture of Vienna at that time was the result of an enormous action by the city council, the size of which is evidenced by the results: in the years 1923-1927, 30 thousand apartments were built. Lodz was dependent on the central government, which was reluctant to agree to an American loan approved by the city authorities, until the economic crisis made it impossible to obtain it. In the light of the above financial difficulties, the efforts of the local government authorities, which in 1928 started building a colony in Polesie Konstantynowskie, should be appreciated all the more. During the implementation of the investment, carried out in two stages and lasting until 1933, over 2,000 workers were employed, thus reducing unemployment. Although the project has not been completed, its history and spatial effects of the constructed part of the estate, numbering about 3 thousand. chambers (927 apartments), constitute a significant card in the fight for the most socially necessary housing, not only on the national but also European arena. The implementation project envisaged the arrangement of 33 residential buildings of various types (cage houses, gallery buildings, mixed cage-gallery structure) in accordance with the latest trends in planning housing estates, rejecting symmetrical-block compositions in favor of linear systems, subject to the principle of proper sunlight and ventilated courtyards. The construction of the completed part of the estate was carried out in two stages. As part of the first stage, in the years 1928-30, 8 residential buildings were erected, covering series I and II. However, the second stage, which lasted until 1933, brought 12 more, making up the third and fourth series. In the scope of the first series, 3 buildings with a cage structure were erected, located in the area of the Al. Unii. Series II included 5 cage buildings facing Srebrzyńska Street with their southern gables. Its continuation consisted of 6 buildings of the 3rd series, including 5 with a cage structure - arranged analogically to the 2nd series, and 1 located along Srebrzyńska Street, as well as 2 gallery buildings erected in this series. The last series included 6 buildings built in the area of the K. Prauss Street. It consisted of 4 cage houses, 1 gallery and a building with a mixed cage and gallery structure. The construction of residential houses was completed. Of the many general facilities planned earlier, 
gospodarowano 4 lokale sklepowe oraz jeden lokal większy zajmujący powierzchnię dwóch mieszkań, w którym obecnie znajduje się biblioteka osiedlowa. Zagospodarowano również zieleńce i zorganizowano ogródki jordanowskie. Po drugiej wojnie światowej uhonorowano częściowo, przynajmniej w zakresie ogólnej dyspozycji przestrzennej, dotyczącej miejsc lokalizacji obiektów użyteczności publicznej, zamierzenia projektantów. Nie dotrzymano jednak wierności programowej poszczególnych budynków. I tak w miejscu pierwotnej pralni i łaźni wzniesiono szkołę. Na terenie przeznaczonym pod budynek kooperatywy wybudowano przedszkole i pawiIon handlowy. Natomiast zdecydowanie błędnym posunięciem było wzniesienie pralni w rejonie przewidzianym dla ochronki, w bliskim sąsiedztwie budynków mieszkalnych z jednej, zaś dużego kompleksu zieleni z ogródkami jordanowskimi z drugiej strony. W miejscu położenia kamienia węgielnego, na południowej ścianie szczytowej budynku otwierającego kolonię od strony centrum miasta, w 1933 roku wmurowano tablicę poświęconą pamięci patrona osiedla Montwiłła Mireckiego, uczestnika tzw. "krwawej środy", która miała miejsce 15.08.1906 roku W Łodzi. Pod względem architektonicznego wyrazu stylistycznego Kolonia Mieszkalna na Polesiu Konstantynowskim charakteryzowała się prostotą form oraz skromną dekoracją, odmiany niejako „ekonomicznej", a więc uznanej w międzywojennej Europie za właściwą dla architektury małych mieszkań. Niestety, w osiedlu budowanym z myślą o ulżeniu niedoli mieszkaniowej robotników i nisko uposażonej inteligencji, zamieszkiwali przeważnie wyżsi urzędnicy państwowi. W 1930 roku, kiedy oddano do użytku pierwsze 8 bloków wysokość czynszu wyraźnie kolidowała z wielkością zarobków robotniczych (miesięcznie od 40 do 100 złotych). W 1932 roku władze miejskie zbudowały na terenie gminy Chojny kilkanaście drewnianych domków barakowych, przeznaczonych m.in. dla eksmitowanych mieszkańców osiedla magistrackiego na Polesiu Konstantynowskim. Przedsięwzięcie nie zostało zatem doprowadzone do końca, ale jego historia, jak i efekty urbanistyczno-architektoniczne zrealizowanej części osiedla, liczącej około 3000 izb, stanowią znamienną kartę w walce o mieszkanie społecznie najpotrzebniejsze nie tylko na arenie krajowej, ale i europejskiej (Sprawozdanie z działalności Zarządu Miejskiego, 1938). [il. 1]

Obok samorządu Łodzi II Rzeczypospolitej, działania w interesującym nas obszarze prowadziły również Z.U.S., T.O.R, F.K.W. czy liczne spółdzielnie mieszkaniowe. O ich udziale w procesie kształtowania przestrzeni i obiektów o charakterze mieszkalnym świadczą zrealizowane w okresie międzywojennym kolonie, osiedla i zespoły zabudowy. Budowę osiedla Z.U.S. w Łodzi prowadzono w latach 1930-32, a więc równolegle z analogiczną akcją na Żoliborzu w Warszawie. Zgodnie z ogólnokrajowymi wytycznymi zastosowano podział na lokale robotnicze i urzędnicze, tworzące odpowiednie typy segmentów i domów. W zależności od wielkości powierzchni mieszkalnej w obu grupach znajdują się po trzy kategorie mieszkań. Najpowszechniej występują lokale dwupokojowe, które podobnie jak w kolonii magistrackiej na Polesiu Konstantynowskim uznano za społecznie najpotrzebniejsze. Wszystkie mieszkania powyżej only the pump pavilion designed by Witold Szereszewski was built. The nearest constructions were probably a laundry room and a local swimming pool, for which an implementation project was prepared. By adapting 6 apartments on the ground floors of the buildings, 4 shop premises and one larger, covering the area of two apartments, which now contains the housing estate library, were created. Lawns were also developed and Jordan gardens were organized. After the Second World War, the designers' intentions were partially honored, at least in terms of the general spatial disposition regarding the location of public utility facilities. However, the plan accuracy of individual buildings was not respected. Thus, a school was built on the site of the original laundry and bathhouse. A kindergarten and a commercial pavilion were built in the area designated for the cooperative building. It was definitely a mistake to build a laundry in the area planned for an orphanage, in close proximity to residential buildings on one side, and a large green complex with Jordan gardens on the other. In 1933, in the place where the cornerstone was laid, on the southern gable wall of the building from the city center, a plaque was built in memory of the patron of the estate, Montwiłł Mirecki, a participant in the so-called "Bloody Wednesday", which took place on August 15, 1906 in Łódź. In terms of architectural stylistic expression, the Residential Colony in Polesie Konstantynowskie was characterized by simplicity of forms and modest decoration, a kind of "economic" variety, and therefore recognized in interwar Europe as appropriate for the architecture of small apartments. Unfortunately, in the housing estate built to alleviate the housing misery of workers and low-income intelligentsia, it was mostly senior state officials that took up residence. In 1930, when the first 8 blocks of flats were commissioned, the amount of rent clearly collided with the salaries of workers (monthly from 40 to 100 PLN). In 1932, the city authorities built a dozen or so wooden barracks in the Chojny commune, intended for lamong others) evicted residents of the municipal estate in Polesie Konstantynowskie. Therefore, the project has not been completed, but its history, as well as the urban and architectural effects of the completed part of the estate, consisting of about 3,000 rooms, constitute a significant card in the fight for the social housing, not only on the national but also European arena. (Local government of the city of Łódź in the years 1928-1932. Report of the City Board, Łódź 1933, pp. $174 \mathrm{ff}$. APŁ, Faculty of Technology, reference number 20083-20098) (ill. 1)

In addition to the local government of Łódź of the Second Republic of Poland, activities in the area of interest to us were also conducted by Z.U.S., T.O.R, F.K.W. or numerous housing cooperatives. Their participation in the process of shaping space and residential buildings is evidenced by the colonies, housing estates and complexes realized in the interwar period. Construction of the Z.U.S. in Łódź, it was 


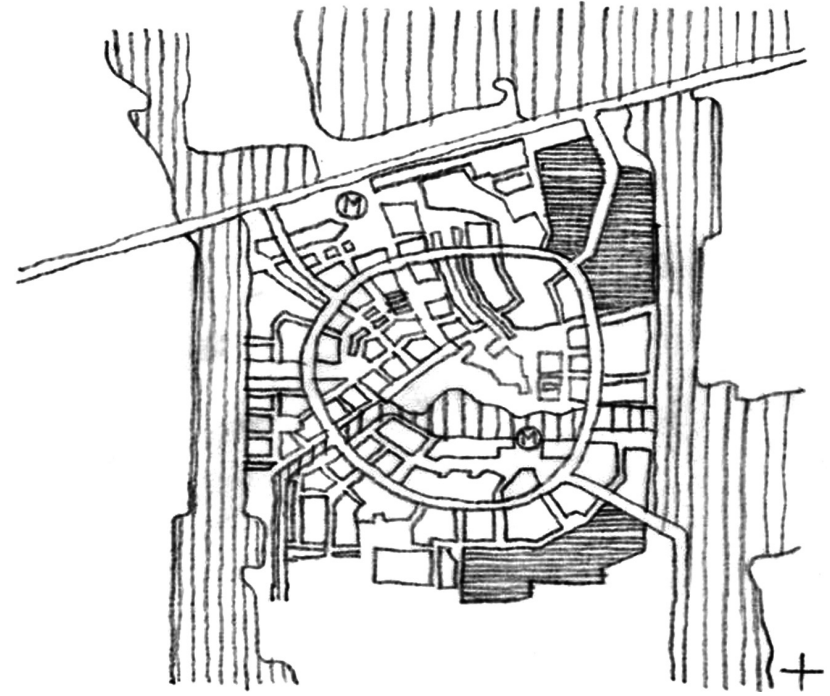

II. 1. Osiedle mieszkaniowe Mątwiłł Mirecki na Polesiu Konstantynowskim w Łodzi, oprac. autorskie / Housing estate Mątwiłł Mirecki in Polesie Konstantynowskie in Łódź, by authors

parteru, nawet najmniejsze, posiadają balkon, są prawidłowo nasłonecznione i w większości przewietrzane. W pierwotnych założeniach zespół miał się składać z 14 budynków mieszkalnych ustawionych w ramach dwóch sąsiadujących kwartałów, w luźnej zabudowie liniowej, generalnie wzdłuż osi północ-południe. Jedynie znikoma, w stosunku do zabudowy o strukturze klatkowej, część o strukturze galeriowej podporządkowana była osi wschód-zachód. W większym kwartale „robotniczym”, między ulicami: A. Dygasińskiego, Bednarską, S. Żółkiewskiego i Sanocką zaplanowano realizację 12 bloków oraz położony centralnie na osi wschód-zachód Park Osiedlowy. W skrajnej zachodniej strefie terenu zlokalizowano dobudowaną do jednego z bloków o strukturze klatkowej, mieszkalną w dolnych kondygnacjach wieżę ciśnień, stanowiącą wspólnie z „wieżami” klatek schodowych sąsiedniego galeriowca, ciekawą dominantę przestrzenno-wysokościową, widoczną już z ulicy Pabianickiej. Wschodni, mniejszy kwartał „urzędniczy”, ograniczony ulicami: Sanocką, S. Żółkiewskiego, Bednarską i Unicką potraktowano jednoprzestrzennie, Iokalizując tutaj dwa bloki o generalnej orientacji zgodnej z resztą zespołu, ale poprzez skrzydła boczne przymykające dziedziniec wewnętrzny, stwarzające obrzeżny układ zabudowy. Podobną zwartą kompozycję obrzeżnej zabudowy zastosował Józef Szanajca (zatrudniony w Biurze Projektów Z.U.S.) w rejonie budynku "Warszawa 2" na Żoliborzu. Projekt, poza urządzeniami terenowymi w postaci ogródków jordanowskich, aneksów gospodarczych oraz wbudowanych pralni i kąpielisk, nie przewidywał żadnych kubaturowych, wolnostojących obiektów użyteczności publicznej. W świetle ograniczonych możliwości finansowych dokumentacją techniczną objęto i w efekcie końcowym zrealizowano jedynie 7 bloków mieszkalnych, w tym oba domy urzędnicze (oba typu klatkowego), zagospodarowujące kwartał mniejszy oraz pięć domów robotniczych (1 typu galeriowego, 2 typu klatkowego z wieżą ciśnień, 2 o strukturze mieszanej klatkowo-galeriowej) w zachodniej strefie drugiego kwartału. Realizację prowadzono zatem syste- carried out in 1930-32, i.e. in parallel with a similar operation in Żoliborz in Warsaw. In accordance with the national guidelines, a division into blue-collar and clerical premises was used, creating appropriate types of segments and houses. Depending on the size of the living space, there are three categories of apartments in both groups. The most common are two-room premises, which, similarly to the town hall in Polesie Konstantynowskie, were considered the most socially necessary. All apartments above the ground floor, even the smallest ones, have a balcony, have access to sunlight and are properly ventilated. In the original assumptions, the complex was to consist of 14 residential buildings arranged in two adjacent quarters, in a loose linear development, mostly along the north-south axis. Only a negligible part of the gallery, in relation to the cage structure in the east-west axis. In the larger "workers" quarter, between the streets: A. Dygasińskiego, Bednarska, S. Żółkiewskiego and Sanocka, the construction of 12 blocks and the Estate Park is in the plans, located centrally on the east-west axis. In the extreme western zone of the site there is a water tower, added to one of the cage-shaped blocks, living space in the lower floors, which together with the "towers" of the staircases of the neighboring gallery building, is an interesting construction, already visible from the $\mathrm{Pa}$ bianicka Street. The eastern, smaller "clerical" quarter, limited by the streets: Sanocka, S. Żółkiewskiego, Bednarska and Unicka, contains two blocks with a general orientation consistent with the rest of the complex, but through side wings closing the inner courtyard, creating a peripheral layout of buildings. A similar compact composition of peripheral buildings was applied by Józef Szanajca (employed at the Design Office of Z.U.S.) in the area of the „Warszawa 2" building in Żoliborz. The project, apart from field devices in the form of Jordan gardens, utility annexes and built-in laundries and bathing areas, did not envisage any large, free-standing public utility buildings. In view of the limited financial possibilities, the technical documentation was reduced and, as a result, only 7 apartment blocks were completed, including both office houses (cage-type houses), filling the smaller quarter and five workers' houses (1 gallery type, 2 cage type with a water tower and 2 mixed - cage and gallery) in the western zone of the second quarter. The implementation was therefore carried out by the system "from the outside to the center of the complex". Utilities for the area included setting up a local water, sewage and electricity network. Currently, it is connected to municipal networks. In the years 1933-34, the Estate Park, much larger than originally planned, was established between two parts of blocks in undeveloped area of about 3 ha. The greenery here integrates both areas spatially and allows it to be perceived as a uniform composition, despite the fact that its concept is only partially implemented. In their structure, the apartments are similar to the variants used by S. Brukalski 
mem „od zewnątrz do środka zespołu”. Uzbrojenie terenu obejmowało założenie lokalnej sieci wodociągowej, kanalizacyjnej i elektrycznej. Obecnie zespół podłączono do sieci miejskich. W latach 1933-34 na terenach niezabudowanych o powierzchni około 3 ha między dwoma partiami bloków założono, dużo większy od pierwotnie planowanego, Park Osiedlowy. Zieleń pełni tu rolę integrującą przestrzennie oba zabudowane rejony i pozwala odbierać zespół jako jednolitą kompozycję, mimo zrealizowania jego koncepcji jedynie w połowie. W swojej strukturze mieszkania są zbliżone do wariantów zastosowanych przez S. Brukalskiego i J. Szanajcę w budynkach "Warszawa 1" i „Warszawa 2". Przy czym, podobnie jak w Warszawie, życie zrewidowało początkowo założone rozgraniczenie mieszkań dla dwóch kategorii lokatorów - robotników i urzędników, które okazało się nierealne i nieistotne. Dla znacznej większości pracowników fizycznych najskromniejsze, najbardziej wnikliwie zaprojektowane i oszczędnie wykonane mieszkania okazały się niedostępne. W tzw. domach robotniczych w większości mieszkali pracownicy umysłowi. Należy jednak przyznać, że w zakresie dostarczenia mieszkań społecznie najpotrzebniejszych, dorobek działalności Stowarzyszenia Budowlano-Mieszkaniowego Z.U.S. w Łodzi był znaczący. (APŁ, Wydział Techniczny, sygnatury 2008320098) [il. 2] Mimo niezrealizowania zespołu w całości przestrzeń osiedla stała się, obok kolonii na Polesiu Konstantynowskim, największym jednorodnym elementem pejzażu architektonicznego miasta w kategorii wielorodzinnych budynków mieszkalnych.

Analiza osiągnięć procesu kształtowania przestrzeni w Łodzi II RP, w kontekście awansu administracyjnego miasta pozwala stwierdzić, że wraz z uzyskaniem ponadlokalnej funkcji w administracji państwowej, kościelnej i wojskowej oblicze architektoniczne ośrodka nabierało wielkomiejskiego wyrazu i wybitnej rangi. Potwierdzenie tego faktu nastąpiło $w$ latach powojennych, kiedy to, niewiele zniszczona przez hitlerowskiego okupanta, Łódź służyła swą przestrzenią ulokowanym w niej przejściowo funkcjom miasta stołecznego. Reminiscencje międzywojennego rozwoju Łodzi są po dzień dzisiejszy odbierane pozytywnie. Zawdzięczamy to wysokiej jakości wykreowanych wówczas przestrzeni, w których ludzie czują się nadal znakomicie. Niezależnie od różnorodności stylistycznej i wartości znaczeniowej tych obiektów we współtworzeniu struktury przestrzeni w Łodzi stanowią one po dzień dzisiejszy ważne elementy i ogniwa podtrzymujące wielkomiejski charakter i winny podlegać szczególnej ochronie.

\section{Osiedle Bata}

Kolejny, trzeci reprezentatywny przykład z okresu międzywojennego wybrany do oceny to Zlin. Miasto leżące na wschodnich Morawach w Czechach. Historycznie uzyskał prawa miejskie w 1397 roku. W okresie międzywojennym powstała tu wielka fabryka butów założona przez rodzinę Bata. W tym też okresie nastąpił jego rozwój. Obecnie jest stolicą kraju zlinskiego. Geneza osiedla dla pracowników to realizacja koncepcji przyfabrycznego idealnego miasta, wzniesionego według zasady panującego funkcjonalizmu epoki modernistycznej. Powstanie tego zespołu datowane jest $w$ literaturze tematu na okres lat pierwszej wojny światowej. W tam- and J. Szanajca in the „Warszawa 1" and "Warszawa 2 " buildings. At the same time, similarly to Warsaw, life revised the initially established division of flats for two categories of tenants - workers and officials, which turned out to be unrealistic and irrelevant. For the vast majority of blue-collar workers, the most modest, most meticulously designed and economically constructed apartments turned out to be unavailable. Mostly white-collar workers lived there. It should be admitted, however, that in the field of providing housing that is socially most necessary, the achievements of the Association of Construction and Housing Z.U.S. in Łódź was significant. (APŁ, Faculty of Technology, reference number 20083-20098) Despite the fact that the complex was not completed, the space of the estate became, next to the colony in Polesie Konstantynowskie, the largest homogeneous element of the architectural landscape of the city in the category of multi-family residential buildings.

The analysis of the achievements of the space shaping process in Łódź of the Second Polish Republic, in the context of the city's administrative advancement, allows us to conclude that with the acquisition of a supra-local function in state, church and military administration, the architectural face of the center acquired a large-city expression and an outstanding rank. This fact was confirmed in the post-war years, when Łódź, not much damaged by the Nazi occupiers, served with its space for the functions of the capital city, temporarily located there. Reminiscences of the interwar development of Łódź are still received positively. We owe it to the high quality of the spaces created at that time, in which people still feel great. Regardless of the stylistic diversity and meaning of these objects, in co-creating the spatial structure in Łódź, they are still important elements and links supporting the metropolitan character and should be subject to special protection.

\section{Bata estate}

Another second representative example from the interwar period selected for evaluation is Zlin, a town in eastern Moravia, The Czech Republic. Historically, Zlin obtained city rights in 1397 . In the interwar period, a large shoe factory was established by the Bata family. Its development took place during this period. Currently, it is the capital of the Zlin region. The genesis of the housing estate for employees is the implementation of the concept of an ideal factory town, built according to the principle of the prevailing functionalism of the modernist era. The establishment has been dated in the literature on the subject from the years of the First World War. During this period, the power in the Zlín town hall was held by social democrats, and later by the communists (1919-1923). With the development of the Bata company, Zlín changed as well, especially after 1923, when Tomáš Bata became mayor. His company built three department stores, a hotel, a cinema, a large hospital, school facilities, science facilities, film studios and thousands 

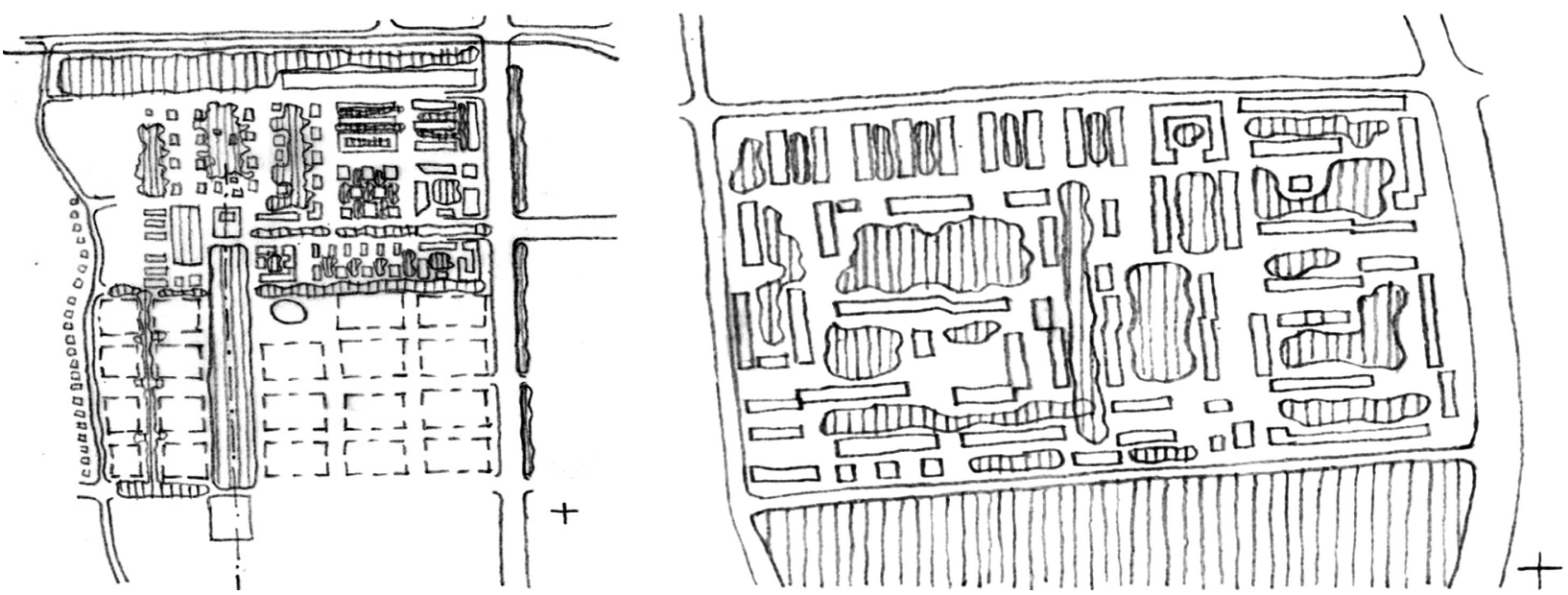

II. 2. Osiedle Bata, oprac. autorskie / Bata housing estate, by authors

II. 3. Sady Żoliborskie w Warszawie, oprac. autorskie / Sady Żoliborskie in Warsaw, by authors

tym czasie władzę w ratuszu dzierżyli socjaldemokraci, a później komuniści (1919-1923). Wraz z rozwojem firmy Bata zmieniał się również Zlín, zwłaszcza po 1923 roku, kiedy burmistrzem został Tomáš Bata. Jego firma zbudowała trzy domy towarowe, hotel, kino, szpital, szkołę, zaplecze naukowe fabryki, studio filmowe i tysiące nowych mieszkań. Zespół kilkudziesięciu nowoczesnych budynków i obiektów powstał na obrzeżach miasta w latach 1923-1938. Przedsiębiorstwo wyposażone w najnowocześniejszy park maszynowy zatrudniało tysiące nowych pracowników. Liczba mieszkańców Zlina wzrosła gwałtownie z 4678 w 1921 r. do 21582 w 1930 r. I 37 342 w 1937 r. Gorączkowa budowa w latach 1923-1938 zmieniła Zlín.[il.3] Jak na owe czasy w hipernowoczesne miasto przemysłowe, oparte na panujących koncepcjach urbanistycznych. Dzieło wybitnych architektów: Jana Kot ra, Františka L. Gahura, Vladimíra Karfíka, Miroslava Lorenca nadało charakter miasta funkcjonalistycznego, unikalnego w Europie. Miasta skupiającego wątki kontaktów biznesowych z niemal całego świata. W najbliższym sąsiedztwie Zlína na Jižní Svahy Południowych Stokach stopniowo rozwijał się park centralny. Dał on możliwości atrakcyjnego spędzania wolnego czasu. Aktualnie na przeciwległych zboczach góry "Tlustá" stopniowo rośnie ścieżka zdrowia, która stwarza idealne warunki zarówno do rekreacji, jak i do bardziej intensywnych zajęć sportowych. Mieszkańcy, jeśli zdecydują się na spacery, jogging, turystykę czy jazdę na rowerze górskim, mogą skorzystać z szeregu oznakowanych szlaków w bliskim sąsiedztwie miasta. Poszczególne trasy prowadzą przez okoliczne malownicze wzgórza. Miasto oferuje odwiedzającym i jego mieszkańcom szereg możliwości spędzenia wolnego czasu w zdrowym stylu dzięki ogromnej ilości zieleni. Dlatego Zlín od dziesięcioleci pozostaje tym, czym był zawsze, zielonym miastem, miastem w ogrodach. Od początku rozbudowy zakładów Bata zwracał uwagę na rolę architektury w budowaniu prestiżu firmy i tworzeniu dobrych warunków do pracy. Zgodnie ze swoją obsesją architektura miała przede wszystkim sprzyjać zwiększaniu wydajności pracy. Powtarzał wciąż: "Nie pozwólmy architektom, aby budowali pomniki!". Dlatego budynki zamiast epatować of new apartments. An extensive complex of several dozen modern buildings and facilities was built on the outskirts of the city in 1923-1938.(Fig.2) The enterprise equipped with the most modern machinery employed thousands of new employees. The population of Zlín increased rapidly from 4,678 in 1921 to 21,582 in 1930 and 37,342 in 1937. The hectic construction in 1923-1938 changed Zlín. At that time, it was a hypermodern industrial city, based on modern urban concepts. The work of outstanding architects: Jan Kotěr, František L. Gahur, Vladimír Karfík, Miroslav Lorenc gave the character of a functionalist city, unique in Europe. a city gathering threads of business contacts from almost all over the world. The central park is gradually growing in the immediate vicinity of Zlín on Jižní Svaha South Slopes. It gives both children and adults the opportunity to spend their free time. On the opposite slopes of the "Tlustá" mountain, it is gradually extended into a health trail, which creates ideal conditions for both recreation and more intense sports activities. The townspeople have many recreational sports opportunities. If they decide to go for walks, jogging, hiking or mountain biking, they can take advantage of a number of marked trails in the vicinity of the city. Routes lead through the surrounding picturesque hills. The city offers visitors and its residents many opportunities to spend their free time thanks to the huge amount of greenery. That is why Zlín has remained for decades what it has always been, a green city, a city in gardens. neighborhood of the city. From the beginning of the expansion of the plants, Bata paid attention to the role of architecture in building the company's prestige and creating good working conditions. In line with his obsession, architecture was primarily supposed to help increase work efficiency. He kept repeating: "Let us not allow architects to build monuments!" Therefore, the buildings, instead of dazzling with decoration and form, were to be functional and ergonomic. The style of the residential houses in Zlin is similar, they are usually 
dekoracją i formą miały być funkcjonalne i ergonomiczne. Stylistyka wszystkich domów mieszkalnych w Zlinie jest bardzo podobna. To najczęściej prostopadłościenne budynki o żelbetowym szkielecie wypełnionym czerwoną cegłą z dużymi oknami. Mówi się wręcz o zlinskiej, bądź batowskiej architekturze. Jednak mimo tych minusów domki, które budowano na zielonych zboczach Zlinu, cieszyły się uznaniem pracowników. Opisuje to w artykule Pokluda Zdeněk (2009). W latach 30. mieszkańcy miasta mówili z dumą, że „na świecie będą tylko trzy wielkie miasta - Berlin, Wiedeń i Zlin”. Prawdziwym twórcą miasta był František Lydie Gahura, autor ogólnej koncepcji urbanistycznej Zlinu. To on stworzył układ prostych ceglanych kostek domów robotniczych, które pokrywały całe zbocza doliny. Choć istniało niewiele ponad 10 wariantów domków, Gahurze udało się uniknąć uniformizmu niekończących się rzędów domów poprzez poprowadzenie ich wzdłuż pofalowanych linii poziomic wzgórza. Rozwinął również metodę budowania wysokościowców w oparciu o żelbetowy szkielet o module 6,15 x 6,15 metra. Tak więc miasto wytwórcy butów spełniło warunki związane z humanistycznym współistnieniem z naturą przestrzeni stworzonej poprzez artystów architektów. To wyjątkowy przykład rozwoju i akceptacji założenia historycznego również przez współczesnych. Jest w pełni przynależny kulturowej wartości miejsca tworząc niepowtarzalny klimat. W badaniach przyjęto ten zespół miejski jako dodatni przykład współgrania tego co stworzyła ręka architektów i wtopienia struktur w istniejące przyrodnicze otoczenie. Te trzy wybrane i omówione zespoły zabudowy mieszkaniowej stanowią przykłady charakterystyczne dla marzenia o mieście idealnym. Są pierwszymi wybranymi przez autorów z serii przedstawicieli reprezentujących przykłady z państw Europy, podlegających w przyszłości badaniom nad strukturami mieszkalnymi kontynentu. Będą to osiedla Anglii, Austrii, Belgii, Francji, Hiszpanii, Niemiec, Węgier i Włoch. Oczywiście również swe miejsce zajmą przestrzenie powstałe w okresie międzywojennym na terenie Rosji. To proces badawczy ewaluacji architektury mieszkaniowej zaplanowany na okres 2020-2023.

\section{Osiedla powojenne}

Kolejne wybrane przykłady pochodzą z powojennego okresu budowy domów i zespołów mieszkaniowych w Polsce Ludowej lat 1945 - 1970. Wielce interesujące są Sady Żoliborskie w Warszawie. Artysta architekt Halina Skibniewska wykształcona w okresie międzywojennym potrafiła wyjątkowo wspaniale kreować przestrzeń. Mówiła: "Tworzenie architektury rodzi się z wielu źródet: wiedzy, analizy, doświadczeń, kontaktów z ludźmi i przyrodą, upodobań estetycznych. Ale projektowanie to już kulminacja w mojej pracy architekta: wówczas już nie myśli się rozdzielnie: "społeczeństwo», "ludzkość", "wielka płyta» - ale poszukuje się syntezy — właściwego wyrazu przestrzennego, architektonicznego. Ogromną rolę w tym procesie odgrywa intuicja". "Jestem jednym z nielicznych warszawskich architektów, którzy nie zaprojektowali żadnego bloku z wielkiej płyty" (Sady Żoliborskie kolonia I - Powojenny Modernizm). Jako architekt Halina Skibniewska w swej twórczości szczególną uwagę zwracała na otoczenie, w którym powstawało założenie urbanistyczne czy też pojedynczy budynek. Jako wybitna rectangular buildings with a reinforced concrete skeleton filled with red brick and large windows. There is even talk of Zlin or Batov architecture. However, despite these disadvantages, the houses, which were built on the green slopes of Zlin, were appreciated by employees. Describes in the article Pokluda Zden k (2009). In the 1930s, city residents proudly said that "there will be only three big cities in the world - Berlin, Vienna and Zlin". The real founder of the city was František Lydie Gahura, the author of the general urban concept of Zlin. It was he who created a system of simple brick cubes of workers' houses that covered the entire slopes of the valley. Although there were just over 10 variants of houses, Gahura managed to avoid the uniformity of the endless rows of houses by tracing them along the undulating lines of the hill's contours. He also developed a method of building high-rise buildings based on a reinforced concrete skeleton with a module of $6.15 \times 6.15$ meters. Thus, the city of a shoe manufacturer fulfilled the conditions related to the humanistic coexistence of created space through artists, architects, and nature. This is a unique example of the development and acceptance of contemporary historical assumptions. It fully belongs to the cultural value of the place, creating a unique atmosphere. Research categorizes this urban complex as a positive example of interaction. These two selected development complexes are so characteristic of the dream of an ideal city. They are the first chosen by the authors from a series of examples from European countries that will be subject to future research on the housing structures of the continent. These will be the estates of England, Austria, Belgium, France, Spain, Germany, Hungary and Italy. Of course, the spaces created in the interwar period in Russia will also have their place. This is a residential architecture evaluation research process planned for the period of 2020-2023.

\section{Post-war housing estates}

The next selected examples come from the post-war period, the time of building houses and residential complexes in People's Poland in the years 1945-1970. An example of great interest is Sady Żoliborskie in Warsaw. The artist and architect, Halina Skibniewska, educated in the interwar period, was able to create an exceptionally wonderful living space. She said: "Creating architecture comes from many sources: knowledge, analysis, experiences, contacts with people and nature, and aesthetic preferences. But design is the culmination of my work as an architect: then you no longer think separately: "society", "humanity", "great slab" - but a synthesis is sought - the proper spatial and architectural expression. Intuition plays a huge role in this process. "I am one of the few architects in Warsaw who did not design any block from a large panel" (Sady Żoliborskie koIonia I - Powojenny Modernizm) As an architect, Halina Skibniewska in her work paid special attention to the surroundings in which the urban layout 
urbanistka zawsze pilnowała by tereny otwarte stanowiły tak samo ważny element koncepcji całości jak zabudowa, a dzięki temu dbała o jakość środowiska mieszkalnego. Wprowadzała duże zespoły terenów zielonych i tereny rekreacyjne jako niezbędne uzupełnienie funkcjonalne projektowanych zespołów. W omawianej kolonii potrafiła tak zaprojektować budynki aby uratować maksymalną ilość istniejących drzew. Dzisiaj określilibyśmy ją architektem ekologiem. Zespół zaprojektowała w latach 60 tych ubiegłego wieku. Jako uzupełnienie funkcjonalne zrealizowano dwa parterowe pawilony ze sklepami i barem mlecznym „Sady“. Budynki zaprojektowane w modernistycznej architekturze. Osiedle to przesądziło o likwidacji istniejących ogrodów działkowych. Likwidacja ogrodu nastąpiła na jesieni 1969 r. Kameralne Sady Żoliborskie I projektowano w latach 1958-62. Halina Skibniewska realizowała je ze współpracownikami, wśród których znalazł się znany później architekt Andrzej Kiciński. Osiedle wspaniale wpisało się w otoczenie zachowując wyjątkowy charakter zespołu wśród zieleni. Świadczy to o wielkiej wrażliwości autorki projektu. "Pragne rozwiązań funkcjonalnych, solidnego wykonania. Dążę do nadania każdemu osiedlu odrębnego, indywidualnego wyrazu poprzez najściślejsze nawiązanie do konkretnych warunków, do atmosfery miejsca, otoczenia, tradycji, historii, krajobrazu. (...) Człowiek, żyjąc w zindywidualizowanym otoczeniu, identyfikuje się z nim łatwiej, jest do niego przywiązany, lubi je, dba o nie" - pisała Halina Skibniewska (Sady Żoliborskie kolonia I - Powojenny Modernizm). Ten przykład również spełnia harmonijnie łączenie funkcji architektury - przestrzeni i natury. Jak się okazuje również w czasach okresu dźwigania polski z ruin można było stworzyć dzieło wielkiej klasy architektoniczno - urbanistycznej. W badaniach stanowi wyjątkowo pozytywny przykład zrealizowanego osiedla nadal darzonego wielką sympatią mieszkańców. Stanowi wzór budowania przestrzeni przyjaznej ludziom. Połączenia harmonijnego natury i nowej struktury tworzonej przy pomocy betonu i cegły. O pięknie osiedla można mówić tak jak określił współcześnie pojmowaną jego rolę w swych rozważaniach Władysław Tatarkiewicz: dziś mówi się raczej o stosowności, właściwości, celowości i funkcjonalności jako zalecie niektórych sztuk i przyczynie upodobania (Tatarkiewicz, 1982, s. 186). To dzieło spełnia wszystkie te określenia. [il. 4]

Piątym przykładem jest osiedle na Kole w Warszawie. Powstało w latach 1947-1950. Spotkało się z krytyką władz ponieważ budynki stworzono w architekturze międzywojennego modernizmu, a nie jak oczekiwano w stylu realizmu socjalistycznego. Architektów zmuszono do złożenia samokrytyki. Współcześnie osiedle uważane jest za jedno z najładniejszych i najlepiej rozplanowanych w Warszawie i Polsce. Domy zaprojektowano zgodnie z zasadami nowoczesnej architektury. Hole wejściowe przeszklone, a ściany ozdobione mozaikami. Zaprojektowano przejścia z projektowanych galerii do mieszkań. Takie rozwiązania wprowadzano już przed wojną. Wpływało to na zwiększenie powierzchnie mieszkań. Osiedle, jako wybitny przykład powojennej architektury modernistycznej, w 2008 roku zostało wpisane do rejestru zabytków. Bloki mieszkalne o płynnych kształtach oraz częściowo niezabudowanych przyziemiach tworzą wrażenie otwartej przestrzeni. Zaprojektowano także or a single building was created. As an outstanding urban planner, she always made sure that open areas were as important an element of the overall concept as the buildings, and thus took care of the quality of the residential environment. She introduced large complexes of green areas. She also took care of recreational areas as a necessary functional addition to the designed complexes. In the colony in question, she was able to design buildings in such a way as to save the maximum number of existing trees. Today we would call her an architect ecologist. The complex was designed in the 60s of the last century. Two one-story pavilions with shops and the "Sady" milk bar were built as a functional supplement. Buildings were designed in modernist architecture. This estate resulted in the liquidation of the existing allotment gardens. The decommissioning of the garden took place in the fall of 1969 with a replacement site in the Bielany District. The Kameralne Sady Żoliborskie I was designed in the years 1958-62. Halina Skibniewska designed them with co-workers, among whom was the later known architect Andrzej Kiciński. The estate fits in perfectly with the surroundings, maintaining its unique character of a green complex. This proves the great sensitivity of the author of the project: "I want functional solutions, solid workmanship. I strive to give each housing estate a separate, individual expression through the closest reference to specific conditions, the atmosphere of the place, surroundings, tradition, history, landscape. (...) Man, living in an individualized environment, identifies himself with it, he is attached to it, likes it, cares for it"- Halina Skibniewska (Sady Żoliborskie kolonia I - Powojenny Modernizm). This example also meets the harmonious combination of the functions of architecture - space and nature. As it turns out, also in the times of lifting Poland from ruins, it was possible to create a masterpiece of great architectural and urban class. In research, it is a very positive example of a completed housing estate that is still very much liked by the inhabitants. It is still a model for building a people-friendly space. A combination of a harmonious nature and a necessary new structure created with concrete and brick. The beauty of the estate can be talked about as Władysław Tatarkiewicz put it in his considerations: "Today it is talked about appropriateness, properties, purposefulness and functionality as an advantage of some arts and a reason for admiration" (Tatarkiewicz, 1982, s. 186). This design fulfills all these terms. (ill. 4)

Another example is the Koło housing estate in Warsaw. It was established in the years 1947-1950. It met with criticism of the authorities because the buildings were created in the architecture of interwar modernism, and not as expected by the authorities in the style of socialist realism. The architects were forced to self-criticize. Nowadays, the estate is considered to be one of the prettiest and best planned in Warsaw and Poland. The houses are designed in accordance with the principles of modern architecture. The en- 


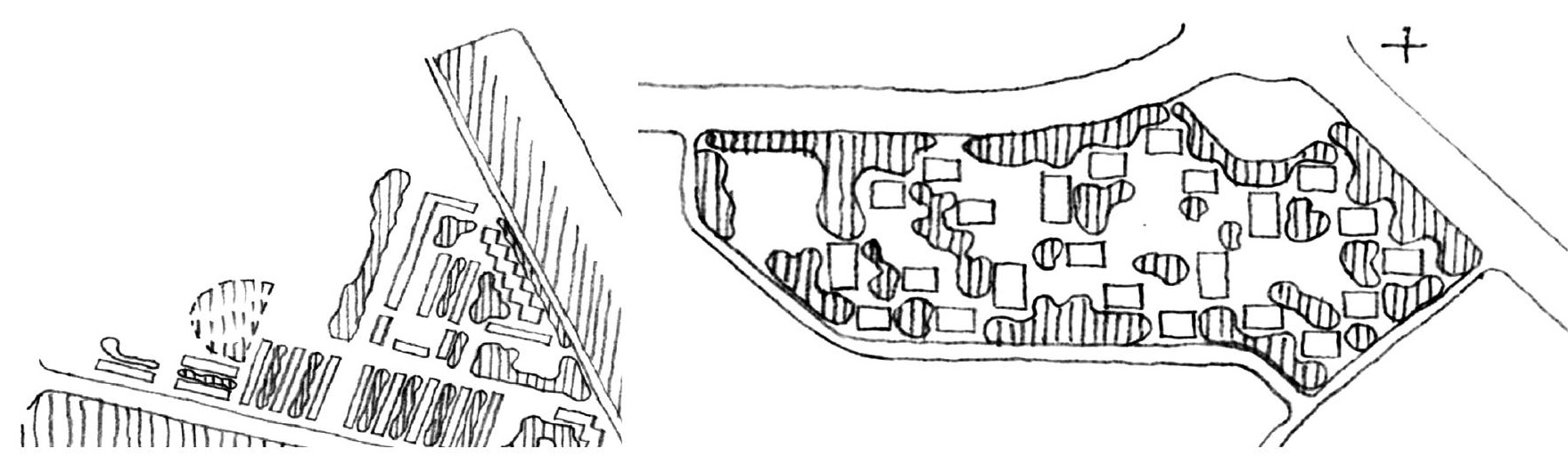

II. 4. Osiedle na Kole w Warszawie / Osiedle na Kole in Warsaw, by authors

II. 5. Kompleks rozwojowy Flugfeld Aspern / Flugfeld Aspern development complex, by authors

infrastrukturę społeczną w postaci szkoły, przedszkola, żłobka i domu społecznego. Mieszkania były małe najczęściej trzypokojowe, o przeciętnej powierzchni 37 metrów kwadratowych. Zastosowano tu po raz pierwszy elementy prefabrykowane, wytworzone z gruzobetonu zwożonego ze zniszczonej Warszawy. Koło przeżywa dziś kolejny rozkwit. Kiedy je oddano do użytku, osiedle było jednym z najnowocześniejszych w kraju. Autorzy projektu Helena i Szymon Syrkusowie idealnie wpasowali różnego rodzaju budynki w tereny zielone. Koło to osiedle przyjazne dla mieszkańców. Architekci pomyśleli również o zapleczu socjalnym dla mieszkańców.[il. 5]

Ostatnim wybranym przykładem z okresu PRL-u jest osiedle Teofilów w Łodzi. Osiedle zabudowane 5-kondygnacyjnymi budynkami mieszkalnymi w konstrukcji z wielkiej płyty. Teofilów na tle innych osiedli z prefabrykatów wyróżnia się dużym udziałem terenów zielonych w postaci parku znajdującego się w jego sąsiedztwie, dużej ilości krzewów i szpalerów drzew wzdłuż ulic. Wiele znaczy również pozostawiona i dosadzona pomiędzy blokami zieleń wysoka. Autorzy zaprojektowali również bardzo interesujący w swej prostej, nieco pudełkowatej formie zespół usługowy. Funkcja zespołu to handel i miejsce na targowisko. Osiedle zaprojektowane zostało w myśl utopijnej koncepcji miasta linearnego Arturo Soria y Mata. W układzie osiedla można wyznaczyć cztery główne strefy wybudowane w latach 1964-77. Strefa zieleni i rekreacji na południe od strefy mieszkalnej, w większości znajdują się poza obrębem osiedla. To tereny o zróżnicowanym charakterze: od łąk biegnących wzdłuż rzeki Jasieniec, przez dawne tereny rolnicze, ogródki działkowe, resztki terenu leśnego w rejonie ulic Zadraż, Tadeusza Kotarbińskiego i Cieplarnianej, aż po tereny sportowe przy ul. Tomasza Judyma. Od północy oddzieloną od zabudowy mieszkaniowej trasą komunikacyjną zaprojektowano i zrealizowano wielką dzielnicę przemysłową. Na szczególną uwagę zasługują $\mathrm{w}$ ramach założenia projekt osiedla Teofilów „C" zaprojektowanego przez architektów Jakuba Wujka, Zdzisława Lipskiego i Jerzego Sadowskiego oraz osiedle Dworzec Chojny zaprojektowanego wraz z architektami Andrzejem Owczarkiem i Krystyną Greger. Twórcy tak kształtowali zespoły mieszkalne i usługowe, aby ich elastyczna struktura umożliwiała dostosowywanie do zmiennych potrzeb. Zespół projektowy wykorzystując tak niewdzięczne tworzywo, jak prefabry- trance halls are glazed and the walls are decorated with mosaics. The building variants include galleries from which the apartments are entered. Such solutions were introduced before the war. This resulted in an increase in the area of flats. The estate, as an outstanding example of post-war modernist architecture, was entered in the register of monuments in 2008. Residential blocks with flowing shapes and partially undeveloped basements create the impression of an open space. The social infrastructure in the form of a school, kindergarten, nursery and social house was also designed. The flats were small, usually three-room, with an average area of 37 square meters. For the first time, prefabricated elements made of rubble concrete transported from destroyed Warsaw were used. Today, WSM Koło is experiencing another boom. When it was opened, it was one of the most modern in the country. The authors of the project, the Syrkus family, perfectly fit various types of buildings into green areas. Koło is a friendly estate for residents. The architects also thought about social facilities for residents. (ill. 5)

The last selected example from the communist period is the Teofilów housing estate in Łódź. Developed with 5-storey residential buildings in a prefabricated structure. Compared to other prefabricated estates, it stands out with a large share of green areas in the form of a park in its vicinity, a large number of squares and trees along the streets. The authors also designed a service complex unit that is very interesting in its simple, slightly box-shaped form. It serves a trade function and as a place for an outdoor market. The estate was designed in accordance with the utopian concept of a linear city by Arturo Soria y Mata. There are four main zones built in the years 1964-77. The green and recreation area south of the residential area is mostly outside the estate. These are areas of a varied nature: from meadows running along the Jasieniec river, through former agricultural lands, allotment gardens, remnants of forest land in the area of Zadraż and Tadeusza Kotarbińskiego Streets, to sports areas at ul. Tomasza Judyma St. Separated from the north by a communication route, a large industrial district was designed and built. The 
kowana płyta elewacyjna i stropowa. Starali się stworzyć środowisko przyjazne użytkownikom. Modularne budynki osiedla były tak ze sobą łączone aby tworzyły formę otwartą. Projektanci przeświadczeni o konieczności wyjścia poza ramy modernistycznych doktryn starali się pokonać schemat tworzenia najprostszych form prostopadłościennych dodając drobne elementy wejść do budynków czy tworząc ciekawy układ urbanistyczny.

Osiedle to jest pozytywnym przykładem stworzonej przestrzeni urbanistycznej wraz z usługami towarzyszącymi. Architektura to niestety typowa wielka płyta. Jej niedomogi funkcjonalno- przestrzenne i małe mieszkania kompensuje otoczenie zieleni. Autorzy przy badaniach nadają temu przykładowi status szczególny ze względu na osiągnięcie przestrzenne mimo dominującej doktryny komunistycznej. Jest wynikiem wysiłku zespołu urbanistów i architektów chcących w okresie tragicznym dla architektury wznieść poprawny przestrzennie zespół. Zrealizowali swe zamierzenie nadając osiedlu indywidualny charakter który z latami zyskał wielu sympatyków wśród mieszkańców.

\section{Współczesny zespół zabudowy Flugfeld Aspern}

Upadek komunizmu w Europie pod koniec lat osiemdziesiątych XX wieku zapoczątkował stabilizację zmian demograficznych i krystalizację rozrostu. W kwietniu 1994 roku został przedłożony do zatwierdzenia Radzie Gminnej Wiednia nowy plan rozwoju miasta - Stadtentwicklungsplan, tzw. STEP, wraz z koncepcją układu komunikacji. STEP i propozycja rozwiązania systemu poruszania się w mieście były z jednej strony ramowym, doraźnym „rozkładem jazdy", który należało na bieżąco, każdorazowo dopasowywać do błyskawicznie zmieniających się wymogów i potrzeb , z drugiej strony musiał stanowić długoterminowy kodeks zasad realizacji ponadczasowych celów, sformułowanych w postaci niżej przedstawionych 10 generalnych wytycznych.

1.Wiedeń rośnie dalej, z nowymi szansami, ale także z nowym ryzykiem.

2.Budownictwo mieszkaniowe jako podstawa socjalnych orientacji polityki komunalnej.

3.Praca dla wszystkich.

4.Prawo do bezpiecznego życia.

5.Miasto ekologiczne.

6.Mobilność dla wszystkich w zwartym mieście.

7.Potrzeba wizji i odwagi, ale także zdolności do szybkiej oceny "na oko" w polityce komunikacyjnej.

8.Zaproszenie mieszkańców do współpracy.

9.Wiedeń - centrum przyszłego regionu.

10.Czas nowej świadomości społecznej i ekologicznej.

Jakie szczegółowe wskazówki i konkretne działania realizacyjne zostały ukryte za tymi nośnymi, sformułowanymi w postaci dekalogu, uniwersalnymi hasłami?

Ad.1. Liczba mieszkańców wielkomiejskiego Wiednia w latach 1981-1991 zwiększyła się o 0,6\%, gdy w tym samym czasie liczba mieszkańców przedmieść wzrosła o $8 \%$. W świetle tych faktów prawidłowa reakcja na przemiany społeczne i demograficzne - komunalna polityka miejska - stała się nakazem chwili. Konsekwencją tego musiała być intensywna kooperacja z całym regionem w zakresie rozwiązywania problemów komunikacyjnych (rozbudowa komunikacji podmiejskiej, przyjaznej project of the Teofilów "C" housing estate designed by architects Wujek, Lipski and Sadowski and the Dworzec Chojny housing estate designed together with architects Owczarek and Greger deserve special attention. The creators shaped residential and service complexes in such a way that their flexible structure could be adapted to changing needs. The design team, using such a thankless material as a prefabricated facade and ceiling slab, tried to create a user-friendly environment. Modular elements were combined to create an open form. At that time, designers, convinced of the necessity to go beyond the framework of modernist doctrines, tried to go beyond the scheme of creating the simplest rectangular forms by adding small elements of entrances to buildings or creating an interesting urban layout. The estate is a positive example of a created urban space with accompanying services. Architecture is, unfortunately, a typical big slab housing. Its functional and spatial deficiencies and small apartments are compensated by the surrounding greenery and park. The authors treat this example in research giving it a plus and minus value. It is, however, an effort by a team of town planners and architects who, in the period tragic for architecture, wanted to build communist doctrines with a spatial correctness due to the poor architectural structure being forced for years.

\section{Contemporary Flugfeld Aspern building complex}

The fall of communism in Europe in the late 1980s initiated the stabilization of demographic changes and the crystallization of growth. In April 1994, a new city development plan - Stadtentwicklungsplan, the so-called STEP, along with the concept of the communication system, came into being. STEP and the proposed solution for the mobility system in the city were, on the one hand, a framework, ad hoc "timetable", which had to be adapted to the rapidly changing requirements and needs on an ongoing basis, on the other hand, it had to be a long-term code of principles for achieving the timeless goals set out in the 10 general guidelines below:

1. Vienna continues to grow with new opportunities but also with new risks.

2. Housing construction as the basis of social orientations of municipal policy.

3. Employment for everyone.

4. The right to a safe life.

5. Eco-friendly city.

6. Mobility for everyone in a compact city.

7. The need for vision and courage, but also the ability to quickly assess "by eye" the transport policy.

8. Inviting residents to cooperate.

9. Vienna - the centre of future region.

10. A time of new social and ecological awareness. What detailed guidelines and specific implementation activities have been hidden behind these popular, universal slogans formulated in the form of the Decalogue? 
środowisku sieci ulicznej i tramwajowej, etc.). W 1993 roku oddano do użytku około 14.000 mieszkań. Prognozy na lata 1994/95 przewidywały oddanie 16-17.000 mieszkań. Prawie 60\% lokali mieszkalnych wzniesiono bądź wygospodarowano w obszarze istniejących zasobów poprzez modernizację i sanację zabudowy w starych częściach miasta. W ramach rozwoju i dalszej rozbudowy nowych rejonów uzyskano:

- Flugfeld Aspern - 4.000 mieszkań + 6.000 miejsc pracy; [il. 6]

- Kagran/Donaufeld - 9.000 mieszkań + 6.000 miejsc pracy.

Ad.2. Rozbudowę miasta w kierunku południowym rozpoczęto w 1993 roku. W następnych latach powstało tutaj prawie 19.000 mieszkań i 11.000 nowych miejsc pracy. Hołdując propagowanej dewizie, iż życie i mieszkanie w mieście końca XX wieku to „ilość idąca w parze z jakością", dla wszystkich objętych inwestowaniem rejonów Wiednia ogłaszano konkursy państwowe (skupiające najlepszych urbanistów, architektów i projektantów zieleni) w celu opracowania optymalnej infrastruktury w zakresie komunikacji zbiorowej czy publicznych miejsc rekreacji i odpoczynku. Przykładowo w 1993 roku przeprowadzono ich 12.

Ad.3. Liczba bezrobotnych w Wiedniu wzrosła z 5,4\% w 1989 roku do 7,2\% w 1993 roku. W 1994 roku Wiedeń miał 67.578 bezrobotnych co stanowiło 8\% aktywnych zawodowo. Szczególny deficyt miejsc pracy zaobserwowano w północnym obszarze miasta w 21 i 22 okręgu (Bezirk), tj. w rejonie, w którym równolegle oddano do użytku dużą ilość mieszkań. W związku z powyższym zahamowano proces rozwoju przestrzeni mieszkalnej w tym regionie, kumulując wysiłki w kierunku tworzenia miejsc pracy, a rozbudowę miasta skoncentrowano w obszarze południowym. Dzięki strategii ochrony istniejących, nawet najmniejszych zakładów produkcyjnych, popieraniu inicjatyw tworzenia nowych przedsiębiorstw, lokowania biur, usług, obiektów handlowych, rozwojowi służb publicznych i społecznych w rejonach zagrożonych największym bezrobociem, w 1993 roku stworzono więcej miejsc pracy - około 19.000, niż oddano do użytku mieszkań. Prognoza na lata 1994/95 przewidywała zorganizowanie 24.000 nowych miejsc pracy. Ad.4. Zapewnienie mieszkania i pracy stanowi bazę dla bezpiecznego życia, ale nie jest wystarczające. Socjalne bezpieczeństwo to także przedszkola, szkoły, budynki na potrzeby ochrony zdrowia i obiekty socjalne, jak również bezpieczne otwarte przestrzenie publiczne (oświetlone, wygodne dla kobiet, atrakcyjne dla dzieci i młodzieży). Należy preferować tolerancję i propagować integrację ze współmieszkańcami obcego pochodzenia, którzy ze swej strony winni przestrzegać zastanych, obowiązujących społecznie reguł i norm. W 1993 roku zaczęto realizować program modelowy „Wiedeń - bezpieczne miasto". Była to wspólna inicjatywa władz miejskich, policji i Instytutu Kryminalno-Socjologicznego. Wspólnie z mieszczanami podejmowano działania rozwijające poczucie bezpieczeństwa, począwszy od wywiadów i zebrań z mieszkańcami na temat lęków i zagrożeń kryminalnych. W ramach tego programu opracowano konkretny projekt nowego ukształtowania, w aspekcie „więcej bezpieczeństwa", rejonu Hermann Leopoldipark.
Ad. 1. The population of metropolitan Vienna increased by $0.6 \%$ between 1981 and 1991, while at the same time the population of the suburbs increased by $8 \%$. In the light of these facts, the correct response to social and demographic changes - municipal urban policy - became the imperative of the moment. The consequence of this had to be intense cooperation with the entire region in the field of solving communication problems (expansion of suburban communication, environmentally friendly street and tram networks, etc.). In 1993, approximately 14,000 apartments were commissioned. Forecasts for 1994/95 showed the completion of 16-17,000 apartments. Almost $60 \%$ of the residential premises were built or managed in the area of the existing resources by modernizing and restructuring buildings in the old parts of the city. The development and further expansion of new regions resulted in:

- Flugfeld Aspern - 4.000 apartments + 6.000 workplaces; (ill. 5)

- Kagran/Donaufeld - 9.000 apartments + 6.000 workplaces.

Ad. 2. The expansion of the city towards the south began in 1993. In the following years, almost 19,000 flats and 11,000 new jobs were created here. In keeping with the propagated motto that life and living in a city of the end of the 20th century is "a quantity that goes hand in hand with quality", state competitions (bringing together the best urban planners, architects and green designers) were announced for all areas of Vienna (covered by the investment) in order to develop optimal communication infrastructure collective or public places of recreation and rest. For example, in 1993, 12 competitions took place.

Ad. 3. The number of unemployed in Vienna increased from $5.4 \%$ in 1989 to $7.2 \%$ in 1993. In 1994, Vienna had 67,578 unemployed, which constituted $8 \%$ of the economically active. A particular shortage of jobs was observed in the northern part of the city in district 21 and 22 (Bezirk), i.e. in an area where a large number of apartments were completed at the same time. As a result, the process of housing development in this region has been halted, efforts to create jobs have been increased, and the expansion of the city has been concentrated in the southern area. Thanks to the strategy of protecting the existing, even the smallest production plants, supporting the initiatives of creating new enterprises, offices, services, commercial facilities, and developing public and social services in regions threatened with the highest unemployment, in 1993 more jobs were created - about 19,000, more than new apartments. The forecast for 1994/95 planned the creation of 24,000 new jobs.

Ad. 4. Providing housing and work is the basis for a safe life, but it is not enough. Social security also includes kindergartens, schools, buildings for health care and social facilities, as well as safe open public spaces (illuminated, comfortable for women, attractive for children and young people). Tolerance 


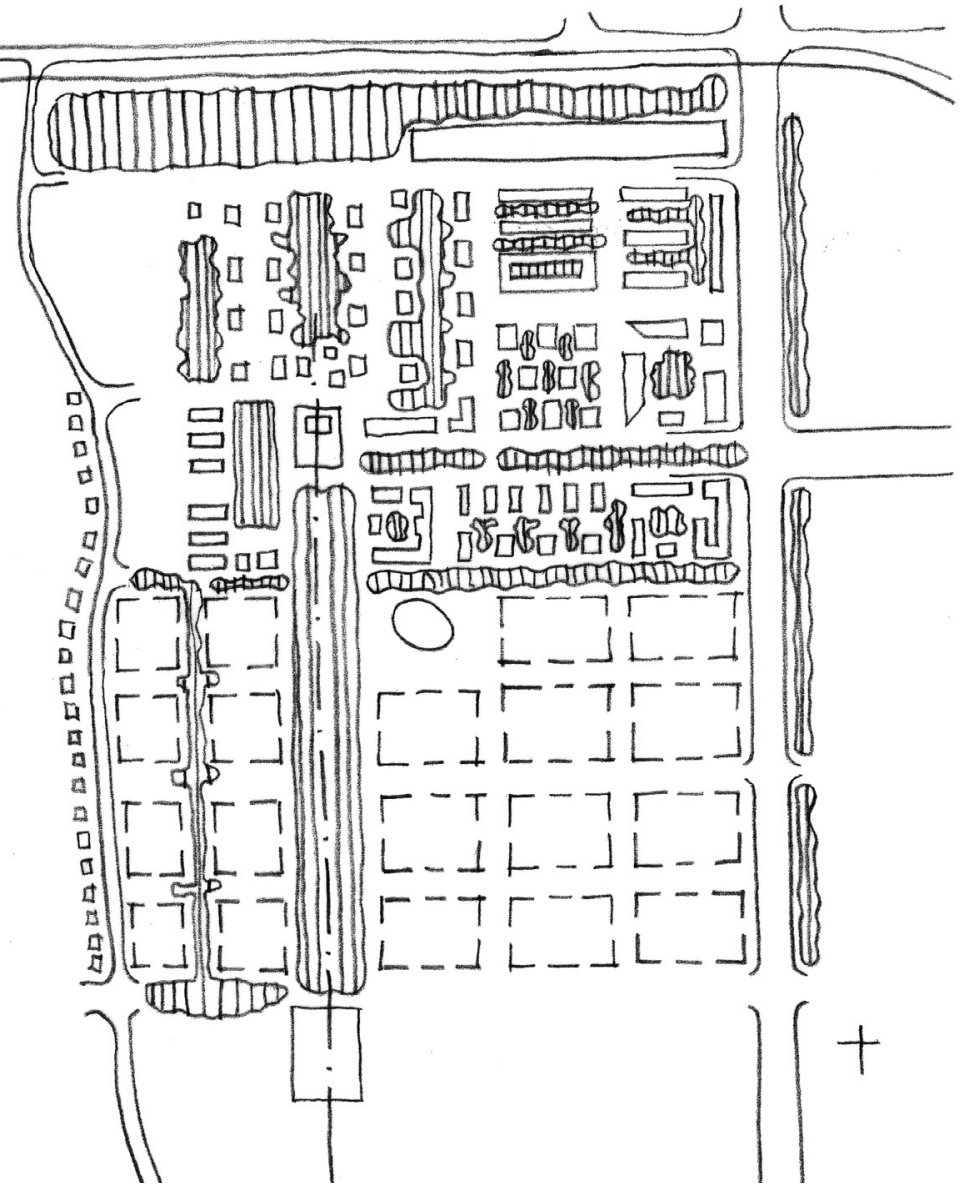

II. 6. Smart City Żerniki we Wrocławiu, oprac. autorskie / Smart City Żerniki in Wrocław, by authors

Rozwinięto koncepcję bogatszego oświetlenia, większej przejrzystości, widoczności etc. otwartych przestrzeni publicznych i terenów mieszkalnych.

Ad.5. Polityka ekologicznego rozwoju miasta znana z poszukiwania metod troskliwego współżycia mieszczan z ziemią i środowiskiem, wychodząc z założenia iż kształtowanie przestrzeni mieszkalnej i miejsc pracy musi sprzyjać ekologii, oparta została o następujące generalne wytyczne (Redzinska, K., \& Jedraszko-Macukow, M., 2013):

- realizowanie wyższej gęstości zabudowy, szukanie rezerw wysokościowych, nadbudowy;

- przytulne otoczenie i wygodne sąsiedztwo między mieszkaniem a pracą, z lepszym podłączeniem do komunikacji masowej;

- rozwój osiedli wzdłuż osi komunikacji masowej (mniej spalin i mniej hałasu);

- wykorzystywanie wewnątrzmiejskich powierzchni, klasycznych luk budowlanych, terenów wojskowych (koszary, przebudowa dworców, remiz, zajezdni);

- realizacja ekologicznych projektów, także w stadium eksperymentalnym, jak na przykład Saikogasse (Miasto Słońca - największy europejski energosłoneczny projekt), czy termalna kotłownia Grundackergasse (zapewniająca energooszczędne ogrzewanie dla 500 mieszkań);

- prawne zabezpieczenie zielonych stref-tabu przez planowanie i celową politykę zakupu gruntów.

Ad.6. "Miasto krótkich dróg" to strategiczne hasło wiedeńskiej komunikacji miejskiej polegające na budowie should be preferred and integration with fellow residents of foreign origin should be promoted, who, on their part, should follow the existing, socially binding rules and norms. In 1993, the "Vienna - Safe City" model program was started. It was a joint initiative of the city authorities, the police and the Criminal Sociological Institute. Together with the townspeople, activities were undertaken to develop the sense of security - interviews and meetings with residents about criminal fears and threats. As part of this program, a concrete project of the new shape of the Hermann Leopoldipark region was developed in the aspect of "more security". The concept of better lighting, greater transparency, visibility, open public spaces and residential areas was developed.

Ad. 5. The policy of ecological development of the city, known for searching for methods of coexistence of townspeople with the land and the environment, assuming that the shaping of living space and workplaces must be favorable to ecology, was based on the following general guidelines (Redzinska, K., \& Jedraszko-Macukow, M., 2013):

- implementation of a higher density of buildings, looking for height reserves, superstructures;

- a friendly environment and a comfortable neighborhood between living and working, with better connection to mass communication;

- development of housing estates along the axis of mass communication (less fumes and less noise);

- using interior spaces, classic building gaps, military areas (barracks, reconstruction of railway stations, fire stations, depots);

- implementation of ecological projects, also in an experimental stage, such as Saikogasse (City of the Sun - the largest European solar energy project) or the Grundackergasse thermal boiler house (providing energy-saving heating for 500 apartments);

legal protection of taboo green zones through planning and targeted land purchase policy.

Ad. 6. "The City of short roads" is a strategic slogan of Viennese public transport consisting of the construction of a dense, tight network of roads, attractive pedestrian spaces, a long-distance network of bicycle paths, wide pavements, transverse passages on the surface, as well as the development of efficient, environmentally friendly, safe mass transport ( U-Bahn + S-Bahn for the region, Bus and tram).

Ad. 7. Conducting a correct communication policy in order to eliminate communication difficulties and reduce the number of accidents requires the ongoing analysis of traffic intensity at different times of the day and correct organization of parking systems within the city and control of the degree of their use. Ad. 8. Constructive cooperation between politicians and decision-makers and townspeople should be developed in terms of settling architectural competitions concerning housing development, expansion of public transport, shaping bicycle paths and bus routes.

Ad. 9. In the area of a united Europe, Vienna should play the role of the center of the Central European 
gęstej, szczelnej sieci dróg, atrakcyjnych przestrzeni pieszych, dalekosiężnej sieci dróg rowerowych, szerokich chodników, poprzecznych przejść na powierzchni, a także na rozbudowie wydajnej, sprzyjającej środowisku, bezpiecznej komunikacji masowej (U-Bahn + S-Bahn dla regionu, Bus i tramwaj).

Ad.7. Prowadzenie prawidłowej polityki komunikacyjnej, w celu likwidacji utrudnień komunikacyjnych i zmniejszania ilości wypadków, wymaga bieżącego analizowania natężenia ruchu w różnych porach doby oraz poprawności organizacji systemów parkowania w obrębie miasta i kontroli stopnia ich wykorzystania.

Ad.8. Należy rozwijać konstruktywną współpracę polityków i decydentów z mieszczanami w zakresie rozstrzygania konkursów architektonicznych dotyczących zabudowy mieszkaniowej, rozbudowy komunikacji miejskiej, kształtowania dróg rowerowych i tras autobusowych.

Ad.9. Wiedeń w obszarze zjednoczonej Europy winien pełnić rolę centrum środkowoeuropejskiego regionu. Odpowiedzialna rola miasta, jako ośrodka łączącego interesy sąsiadów w ramach nowej Europy, wymaga stworzenia optymalnego pola do działania dla międzynarodowych inwestorów.

Ad.10. Nadeszła pora tworzenia współczesnej odpowiedzialności społecznej za zmiany demograficzne, socjalne i przemiany ekologiczne w mieście i regionie. Wymaga to nieustannej, konsekwentnie prowadzonej edukacji i przygotowania mieszczan do światłego współżycia w ramach społeczności lokalnej, wypracowania w nich poczucia przynależności do modernizowanej i nowo kształtowanej przestrzeni, nawiązania zatraconych w czasach globalizacji bezpośrednich więzi sąsiedzkich.

\section{Budujemy dzisiaj dla Łodzi jutra}

Jak wynika z dekalogu, będącego zbiorem zasad służących realizacji procesu rozwoju miasta w myśl mądrej dewizy „Budujemy dzisiaj dla Wiednia jutra”, centralne złożenie wiedeńskiej strategii miejskiej dotyczy tradycyjnie ulepszania warunków mieszkaniowych, a przy tym jakości życia wszystkich obywateli miasta (Urząd Miasta Wiednia, 04.2004.). I właśnie to nadrzędne założenie, będące wytyczną ponadczasową i istniejącą ponad uwarunkowaniami geo-polityczno-ekonomicznymi, można by, niezależnie od różnic dzielących oba miasta, spróbować odnieść do Łodzi.

Spośród generalnych wytycznych wiedeńskiej polityki ekologicznego rozwoju miasta, dla kształtowania przestrzeni w Łodzi w kontekście troskliwego współżycia mieszkańców z ziemią i środowiskiem należałoby zastosować następujące metody:

- realizować wyższą gęstość zabudowy w terenach uzbrojonych poprzez szukanie rezerw wysokościowych, nadbudowy, modernizację i zagospodarowanie setek niewykorzystanych poddaszy w strefie wielkomiejskiej, ograniczając ekspansję w kierunku przedmieść i niekontrolowany rozrost miasta;

- rozwijać osiedla wzdłuż osi racjonalnie zorganizowanej, przyjaznej środowisku komunikacji masowej, w przytulnym otoczeniu i wygodnym sąsiedztwie między mieszkaniem a pracą (mniej spalin i hałasu);

- wykorzystywać zaniedbane wewnątrzmiejskie obszary, klasyczne luki budowlane, tereny po przemysłowe, region. The important role of the city as a center connecting the interests of its neighbors within the new Europe requires creating an optimal field for international investors to act.

Ad. 10. The time has come to create contemporary social responsibility for demographic, social and ecological changes in the city and region. This requires constant, consistent education and preparation of the townspeople for a brilliant coexistence within the local community, developing in them a sense of belonging to the modernized and newly shaped space, establishing direct neighborly ties lost in the times of globalization.

\section{We are building today for the Łódź of tomorrow}

As can be seen from the Decalogue, which is a set of principles for the implementation of the city development process in line with the wise motto "We are building today for the Vienna of tomorrow", the central theme of the Viennese city strategy is traditionally about improving housing conditions and, at the same time, the quality of life of all city citizens. (Vienna City Hall, 04.2004). And it is this overarching assumption, which is a timeless guideline that exists above geo-political and economic conditions, that, regardless of the differences between the two cities, one could try to apply to Łódź.

Among the general guidelines of the Viennese policy of ecological city development, the following methods should be used to shape the space in Łódź in the context of the caring coexistence of its inhabitants with the land and the environment:

- create a higher density of buildings in developed areas by looking for high-altitude reserves, superstructures, modernization and development of hundreds of unused attics in the metropolitan area, limiting expansion towards the suburbs and uncontrolled urban growth;

- develop housing estates along the axis of rationally organized, environmentally friendly mass communication, in a cozy environment and comfortable neighborhood between the apartment and work (less fumes and noise);

- use neglected inner-city areas, classic building gaps, post-industrial areas, reconstruct railway stations, depots, fire stations, and factory buildings;

- implement ecological projects, also in the experimental stage (boiler house in Stoki, wind generators);

- legally secure green zones - taboo by planning and purposeful land purchase policy (a strategy successfully used in the interwar period in relation to the shaping of parks and urban green areas), protect river valleys and city ventilation channels.

\section{Wilanów town}

Miasteczko Wilanów in Warsaw is a Polish example of a large residential complex being erected based on the Master Plan. This is the first such housing estate in Poland. Wilanów was designed as an ex- 
przebudowywać dworce, zajezdnie, remizy, budynki po fabryczne;

- realizować ekologiczne projekty, także w stadium eksperymentalnym (kotłownia na Stokach, generatory wiatrowe);

- prawnie zabezpieczać zielone strefy - tabu przez planowanie i celową politykę zakupu gruntów (strategia z powodzeniem stosowana w okresie międzywojennym w odniesieniu do kształtowania parków i zieleńców miejskich), chronić doliny rzeczne i kanały przewietrzania miasta.

\section{Miasteczko Wilanów}

Miasteczko Wilanów w Warszawie to polski przykład wznoszonego dużego zespołu mieszkalnego w oparciu o Master Plan. To pierwsze takie osiedle w Polsce. Wilanów projektowano jako wyjątkowo dużą strukturę osiedlową. Założenie projektu to stworzenie zespołu w oparciu o ideę miasta w mieście. Miało mieć taką strukturę aby mieszkańcy poruszali się pieszo, lub na rowerze. Koncepcję tego prawie 170 hektarowego osiedla stworzył wraz ze swoim biurem Investment Environments Guy C. Perry, architekt, urbanista francusko-amerykańskiego pochodzenia. Miasteczko Wilanów powstaje na terenie Wilanowa Zachodniego. Główny plan osiedla powstał w oparciu o plany miejscowe zagospodarowania terenu m.p.z.t. rejonu Wilanowa Zachodniego i m.p.z.t. Przedpola Pałacu Wilanowskiego. Założeniem jest aby wszystkie budynki mieszkalne osiedla posiadały parkingi podziemne. Partery budynków mieszkalnych mogą być funkcjami usługowymi. W planach przewidziano jedynie 5 kondygnacyjne budynki o wysokości do 20 metrów. Ostatnie kondygnacje podobnie jak w planach Gdyni miały być cofnięte w głąb traktu, na dachach przewidziano tarasy. Wjazdy do parkingów podziemnych tak ukryte, aby nie dominowały w krajobrazie. Klatki schodowe przeszklono, by zachęcić mieszkańców do chodzenia po schodach. Elewacje, poprzez zastosowanie dobrych materiałów miały nawiązywać do elegancji założenia Pałacu Wilanowskiego. Plan oparto na wynikach najnowszych badań dotyczących zrównoważonego planowania miejskiego. Wykonano szereg ankiet aby przebadać życzenia przyszłych mieszkańców. Przewidziano, że wiele zespołów projektowych będzie uczestniczyło w tworzeniu wizerunku architektonicznego osiedla - miasta. Zaproszeni mieli stworzyć budynki spójne z koncepcją, ale nie identyczne. W ramach osiedla zaprojektowano miejsce na ratusz, centrum kulturalno-handlowo-rozrywkowe, sferę kulturalną, wypoczynkową, biurową i religijną. Osiedle tworzy siatka ulic z kwartałami zabudowy, które od strony głównej ulicy tworzą pierzeje, a od wnętrz zielone dziedzińce dla mieszkańców. System oparty o historyczne i nowo projektowane osie kompozycyjne i widokowe al. Wilanowska, Oś Królewska, al. Rzeczypospolitej, ul. Klimczaka. Plan główny określił dominanty dla całego zespołu, którymi jest Pałac w Wilanowie i Świątynia Opatrzności Bożej. Zaplanowane zostały place miejskie, które są częścią ciągłego, otwartego systemu przestrzeni publicznych i półpublicznych.

Podobnie jak w Zlinie przewidziano wiele terenów do wspólnej rekreacji. Punktem charakterystycznym było założenie braku ogrodzeń i reklam. Osiedle - miasto ma pomieścić docelowo 30 tysięcy mieszkańców. Krytycy ceptionally large housing estate structure. The assumption of the project is to create a team based on the idea of a city within a city. Generally, it was to be structured in such a way that the inhabitants could move around on foot or by bike. The concept of this almost 170 hectare estate was created by Guy C. Perry, an architect and urban planner of FrenchAmerican origin, together with his office, Investment Environments. Miasteczko Wilanów is being built in the area of West Wilanów. The main plan of the estate was created on the basis of local land development plans the area of West Wilanów and the Capital City of Warsaw Foreground of the Wilanów Palace. The design is that all residential buildings of the estate should have underground parking lots. Residential ground floors can provide utility services. The last floors, the plans include only 5 - storey buildings up to 20 meters high. The last storeys, as in the plans of Gdynia, were to be located back into the track, with terraces on the roofs. The entrances to the underground car parks are hidden so as not to dominate the landscape. The staircases are glazed to encourage residents to climb the stairs. The elevations, through the use of good materials, were to refer to the elegance of the Wilanów Palace. The plan was based on the results of the latest research in sustainable urban planning. A number of surveys were carried out to examine the wishes of future residents. It was expected that many design teams will participate in creating the architectural image of the estate - the city. The invited parties were to create buildings consistent with the concept, but not identical. As part of the estate, a place was designed for the town hall, a cultural, shopping and entertainment center, as well as a cultural, leisure, office and religious sphere. The estate consists of a network of streets with quarters of buildings, which form frontages from the main thoroughfare and green courtyards for residents from the inside. A system based on historical and newly designed compositional and viewing axes - Wilanowska Avenue, The Royal Axis, Rzeczpospolitej Avenue, Klimczak Street. The master plan defined the main buildings of the entire complex, which are the Wilanów Palace and the Temple of Divine Providence. City squares have been planned, which are part of a continuous, open system of public and semi-public spaces. As in Zlin, there are many areas for shared recreation. A characteristic point was the assumption that there were no fences and advertisements. The estate - the city is to accommodate 30,000 inhabitants. Critics of the design, or rather its implementation, say: "This is not a real city. Where are public squares and public parks?" Although in terms of public spaces, the estate still stands above the Warsaw average. The problem lies with the developers who forget about the concept of the town as an integrated and selfsufficient district. Each of them focuses on their own development teams. The design has won many awards, including the "ULI Global Award for Excel- 
założenia a właściwie jego realizacji mówią: To nie jest prawdziwe miasto. Gdzie są publiczne place i ogólnodostępne parki?. Choć pod względem przestrzeni publicznych osiedle i tak wybija się ponad warszawską średnią. Problem leży po stronie deweloperów którzy zapominają o koncepcji miasteczka jako zintegrowanej i samowystarczalnej dzielnicy. Każdy z nich skupia się na własnych zespołach zabudowy. Założenie to zdobyło wiele wyróżnień między innymi jest nagrodzone „ULI Global Award for Excellence 2010".

Do dnia dzisiejszego brak wielu elementów uzupełniających strukturę jak choćby zespoły ulic - alei. Funkcjonują jedynie te które były niezbędne do oddania budynków do użytkowania. Nie ma praktycznie żadnej przestrzeni publicznej. Park Ostoja Wilanów jest zamknięty i należy do jednego z osiedli. Na dzisiaj mieszkańcy oprócz balkonów i nieużytków na obrzeżach Miasteczka Wilanów nie mogą korzystać ze wspólnych przestrzeni. Trudno zatem mówić o integracji społecznej. Zamknięte osiedla uniemożliwiają spacerowanie między blokami. Zostaje spacerowanie wzdłuż ulic lub po własnym patio. Mimo tych niedociągnięć realizacyjnych, zespół jest generalnie w budowie. Daje to nadzieję na realizację w przyszłości wszystkich publicznych przestrzeni. Po ich wykonaniu będzie to pozytywny przykład procesu zrównoważonego rozwoju struktury metropolitarnej. Autorzy ocenili ten stan, co prawda w trakcie realizacji, jako poziom jedynie dostatecznego działania wobec zrównoważenia tworzonej przestrzeni i natury.

\section{Osiedle w Konstantynowie Łódzkim}

Dziewiąte rozważane osiedle stanowi zespół zabudowy o charakterze niskoenergetycznym i funkcji osiedla budżetowego w Konstantynowie Łódzkim. Osiedle realizowane od roku 2010. Przewidziane ukończenie to rok 2021. Idea osiedla opierała się głównie na stworzeniu zespołu odpowiadającego na zapotrzebowanie, estetycznego, niewielkiego mieszkania od 45-65 metrów kwadratowych, dostępnego dla młodych osób, taniego w utrzymaniu. Zaprojektowano zespół 5 budynków 4 kondygnacyjnych z dostępnym terenem zielonym ulokowanym wewnątrz układu. Ponieważ przez teren przebiega sporych rozmiarów rów melioracyjny postanowiono wykorzystać go do poprowadzenia nad jego brzegami ciągu pieszego z nowymi nasadzeniami zieleni wysokiej. Teren ten miał nadać indywidualny charakter osiedla wzbogacając i urozmaicając warunki życia mieszkańców. Funkcjonalnie osiedle wyposażone zostato w garaże podziemne i system skarp je osłaniających. Pozostałe miejsca postojowe ulokowano w zewnętrznej strefie pomiędzy ulicami i zabudową. Zazielenienie zespołu jest warunkiem uzyskania przyjaznej struktury nawiązującej do charakteru miasta. Starano się zachować bardzo naturalne powiązania pomiędzy wielkością, przestrzenią kreowaną przez kubatury budynków, naturą przenikającą się przez nie.

Udało się zrealizować wszystkie zamierzenia projektowe i programowe. Czas pokaże na ile mieszkańcy tworząc nowe środowisko życia będą dodawać kolejne wartości wspólne do założenia wzbogacając je o nowe elementy. Krajobraz kulturowy dla projektantów w czasie powstania był ważnym elementem odniesienia. Zespół lence 2010". To this day, there are many missing elements required to complete the structure, such as street complexes. Only those that were necessary to put the buildings into operation are functioning. The complex has virtually no public space. The Ostoja Wilanów Park is closed and belongs to one housing estate. Today, the residents, apart from balconies and land on the outskirts of Miasteczko Wilanów, cannot use common spaces. Therefore, it is difficult to talk about social integration. Closed estates make it impossible to walk between the blocks. All you have to do is walk along the streets or on your own patio.

\section{Housing estates in Konstantynów Łódzki}

The eight housing estate under consideration is a low-energy development complex that functions as a budget housing estate in Konstantynów Łódzki. The estate has been implemented since 2010. The planned completion is 2021. The idea of the estate was based mainly on the creation of a demand-driven complex, an aesthetic, small apartment of 45-65 square meters, accessible to young people, cheap to maintain. A complex of 54 -storey buildings has been designed with an accessible green area located inside the layout. Since a large drainage ditch runs through the area, it was decided to use it to lead a pedestrian route with new plantings of high greenery along its banks. This area was to give an individual character to the estate by enriching and diversifying the living conditions of the inhabitants. Functionally, the estate was equipped with underground garages and a system of slopes protecting them. The remaining parking spaces are located in the outer zone between the streets and buildings. A green complex is a condition for obtaining a friendly structure referring to the character of the city. Efforts were made to maintain very natural connections between the size, the space created by the cubic volumes of the buildings and the permeating nature. All design and program plans were successfully implemented. Time will show to what extent the inhabitants, when creating a new living environment, will add further common values to the design, enriching it with new elements. The cultural landscape for designers at the time of the construction was an important reference element. The complex is a socially accepted new tissue of the city. It is difficult to assess the nature of the complex and its architecture, to what extent it is avant-garde. The task was to design calm, classical forms in construction so that they would fit into the existing urban surroundings.

\section{The open city of Żerniki}

The last example considered is a housing estate, an open city, a continuation of the wonderful ensembles of the interwar period, that idealistic idea of a sustainable city space, today called Smart City Żerniki in Wrocław. From the idea of the estate - the city, the architects established a set of goals that were included in two thematic lists. Here are the above-mentioned 
Tab. 1. Tabelaryczna ocena relacji charakteru architektury, przestrzeni i natury w badanych zespołów zabudowy mieszkaniowej (oprac. autorskie).

\begin{tabular}{|c|c|c|c|c|c|c|c|}
\hline $\begin{array}{l}\text { nazwa } \\
\text { osiedla }\end{array}$ & $\begin{array}{c}\text { data } p \\
\text { owstania }\end{array}$ & wielkość & funkcje & $\begin{array}{c}\text { charakter } \\
\text { architektury }\end{array}$ & $\begin{array}{l}\text { wpisanie } \\
\text { w układ } \\
\text { miasta }\end{array}$ & $\begin{array}{l}\text { akcep- } \\
\text { tacja czy } \\
\text { negacja }\end{array}$ & $\begin{array}{c}\text { ocena relacji } \\
\text { architektura- } \\
\text { przestrzeń- } \\
\text { natura }\end{array}$ \\
\hline $\begin{array}{l}\text { Mątwiłła } \\
\text { Mireckiego } \\
\text { Łódź }\end{array}$ & $1928-1933$ & 50 ha & $\begin{array}{l}\text { mieszkaniowa } \\
+ \text { usługi / brak } \\
\text { realizacji / }\end{array}$ & modernizm & $\begin{array}{l}\text { bardzo } \\
\text { dobre }\end{array}$ & akceptacja & doskonała \\
\hline $\begin{array}{l}\text { Osiedle } \\
\text { ZUS Łódź }\end{array}$ & $1930-1932$ & 10 ha & mieszkaniowa & modernizm & $\begin{array}{l}\text { bardzo } \\
\text { dobre }\end{array}$ & akceptacja & doskonała \\
\hline $\begin{array}{l}\text { Zlin } \\
\text { Czechy }\end{array}$ & $1923-1938$ & $\begin{array}{l}\text { Obecnie } \\
\text { ponad } \\
100 \mathrm{~km}^{2}\end{array}$ & miasto & modernizm & $\begin{array}{l}\text { bardzo } \\
\text { dobre }\end{array}$ & akceptacja & dobra \\
\hline $\begin{array}{l}\text { Sady } \\
\text { Żoliboskie } \\
\text { Warszawa }\end{array}$ & 1958 - 1962 & 6 ha & $\begin{array}{l}\text { mieszkaniowa } \\
+ \text { usługi }\end{array}$ & modernizm & $\begin{array}{l}\text { bardzo } \\
\text { dobre }\end{array}$ & akceptacja & doskonała \\
\hline $\begin{array}{l}\text { Koło } \\
\text { Warszawa }\end{array}$ & $1947-1950$ & 24 ha & $\begin{array}{l}\text { mieszkaniowa } \\
+ \text { usługi }\end{array}$ & modernizm & $\begin{array}{l}\text { bardzo } \\
\text { dobre }\end{array}$ & akceptacja & doskonała \\
\hline $\begin{array}{l}\text { Teofilów } \\
\text { Łódź }\end{array}$ & $1964-1977$ & 115 ha & $\begin{array}{l}\text { mieszkaniowa } \\
\text { + usługi / } \\
\text { częściowa real- } \\
\text { izacja }\end{array}$ & wielka płyta & dobre & $\begin{array}{l}\text { akceptacja } \\
\text { częściowa }\end{array}$ & dobra \\
\hline $\begin{array}{l}\text { Aspern } \\
\text { Wiedeń }\end{array}$ & $1993-2028$ & 240 ha & $\begin{array}{l}\text { mieszkaniowa } \\
+ \text { usługi + } \\
\text { przemysł } \\
\text { / w realizacji / }\end{array}$ & $\begin{array}{l}\text { neomoder- } \\
\text { nizm }\end{array}$ & $\begin{array}{l}\text { bardzo } \\
\text { dobre }\end{array}$ & akceptacja & dobra \\
\hline $\begin{array}{l}\text { Wilanów } \\
\text { Warszawa }\end{array}$ & $2002-$ & 160 ha & $\begin{array}{l}\text { mieszkaniowa } \\
+ \text { usługi / } \\
\text { w realizacji / }\end{array}$ & $\begin{array}{l}\text { neomodern- } \\
\text { izm }\end{array}$ & dobre & $\begin{array}{l}\text { akceptacja } \\
\text { częściowa }\end{array}$ & dostateczna \\
\hline $\begin{array}{l}\text { Konstan- } \\
\text { tynów } \\
\text { Łódzki }\end{array}$ & $2010-2020$ & 2 ha & mieszkaniowa & $\begin{array}{l}\text { tradycyjny } \\
\text { modernizm }\end{array}$ & dobre & $\begin{array}{l}\text { akceptacja } \\
\text { częściowa }\end{array}$ & dostateczna \\
\hline $\begin{array}{l}\text { Żerniki } \\
\text { Wrocław }\end{array}$ & $2013-$ & $\begin{array}{l}10 \text { ha I } \\
\text { etap }\end{array}$ & $\begin{array}{l}\text { mieszkaniowa } \\
+ \text { usługi / } \\
\text { w realizacji }\end{array}$ & $\begin{array}{l}\text { neomodern- } \\
\text { izm }\end{array}$ & $\begin{array}{l}\text { bardzo } \\
\text { dobre }\end{array}$ & $\begin{array}{l}\text { akceptacja } \\
\text { częściowa }\end{array}$ & dobra \\
\hline
\end{tabular}

jest akceptowaną społecznie nową tkanką miasta. Trudno ocenić charakter założenia i jego architekturę na ile są awangardowe. Zadaniem bowiem było zaprojektowanie spokojnych form dość klasycznych w budowie tak aby wpisały się w istniejące otoczenie miejskie.

\section{Miasto otwarte Żerniki}

Ostatni przykład rozważany to osiedle, miasto otwarte, kontynuacja wspaniałych zespołów okresu międzywojennego, idealistycznej myśli o przestrzeni miasta, zrównoważonej, dzisiaj nazwanej Smart City Żerniki we Wrocławiu. Od postawienia idei osiedla - miasta, architekci ustalili zespół przyjętych założeń które zostały zapisane w dwóch zestawieniach tematycznych. Oto w/w zestawy zaprezentowane $w$ broszurze opisującej ideę (Plan osiedla - Nowe Żerniki (WUWA2) - Wrocław - oficjalny serwis modelowego osiedla).

ZAŁOŻENIA OGÓLNE,URBANISTYCZNE:

- przestrzenie publiczne służące mieszkańcom: integracja, rekreacja

- usługi podstawowe: opieka nad dzieckiem, edukacja, handel, gastronomia

- bezpieczeństwo sets presented in the brochure describing the idea (Estate plan - Nowe Żerniki (WUWA2) - Wrocław - official website of model estate).

GENERAL, URBAN ASSUMPTIONS:

- public spaces serving residents: integration, recreation

- basic services: childcare, education, trade, gastronomy

- safety

- counteracting social exclusion

- ecology, minimization of operating expenses

- voptimization of communication - cooperation with the public transport system

- new forms of construction planning

- social cooperation

FUNCTIONAL AND ARCHITECTURAL

ASSUMPTIONS:

- private, semi-private, semi-public and public spaces

- optimization of the housing structure

- local traditions in materials and workmanship

- workplace: small spaces dedicated to professional activities 
Tab. 7. Tabular assessment of the relationship between the nature of architecture, space and nature in the researched residential complexes

\begin{tabular}{|c|c|c|c|c|c|c|c|}
\hline $\begin{array}{l}\text { Name of the } \\
\text { housing es- } \\
\text { tate }\end{array}$ & $\begin{array}{l}\text { Date of } \\
\text { creation }\end{array}$ & Size & Functions & $\begin{array}{l}\text { The charac- } \\
\text { ter of archi- } \\
\text { tecture }\end{array}$ & $\begin{array}{l}\text { Imple- } \\
\text { mented } \\
\text { into the } \\
\text { city plan }\end{array}$ & $\begin{array}{l}\text { Acceptance or } \\
\text { negation }\end{array}$ & $\begin{array}{l}\text { Grading the archi- } \\
\text { tecture - natural } \\
\text { space relation }\end{array}$ \\
\hline $\begin{array}{l}\text { Mątwiłła } \\
\text { Mireckiego } \\
\text { Łódź }\end{array}$ & $\begin{array}{l}1928- \\
1933\end{array}$ & 50 ha & $\begin{array}{l}\text { residential + } \\
\text { servics/no im- } \\
\text { plementation }\end{array}$ & modernism & very good & acceptance & perfect \\
\hline $\begin{array}{l}\text { Osiedle ZUS } \\
\text { Łódź }\end{array}$ & $\begin{array}{l}1930- \\
1932 \\
\end{array}$ & 10 ha & residential & modernism & very good & acceptance & perfect \\
\hline $\begin{array}{l}\text { Zlin } \\
\text { Czechy }\end{array}$ & $\begin{array}{l}1923- \\
1938\end{array}$ & $\begin{array}{l}\text { Current- } \\
\text { ly over } \\
100 \mathrm{~km}^{2}\end{array}$ & city & modernism & very good & acceptance & good \\
\hline $\begin{array}{l}\text { Sady } \\
\text { Żoliboskie } \\
\text { Warszawa }\end{array}$ & $\begin{array}{l}1958- \\
1962\end{array}$ & 6 ha & $\begin{array}{l}\text { residential + } \\
\text { servics }\end{array}$ & modernism & very good & acceptance & perfect \\
\hline $\begin{array}{l}\text { Koło } \\
\text { Warszawa }\end{array}$ & $\begin{array}{l}1947- \\
1950\end{array}$ & 24 ha & $\begin{array}{l}\text { residential + } \\
\text { servics }\end{array}$ & modernism & very good & acceptance & perfect \\
\hline $\begin{array}{l}\text { Teofilów } \\
\text { Łódź }\end{array}$ & $\begin{array}{l}1964- \\
1977\end{array}$ & 115 ha & $\begin{array}{l}\text { housing }+ \text { ser- } \\
\text { vices / partial } \\
\text { implementa- } \\
\text { tion }\end{array}$ & modernism & great plate & $\begin{array}{l}\text { partial accep- } \\
\text { tance }\end{array}$ & good \\
\hline $\begin{array}{l}\text { Aspern } \\
\text { Wiedeń }\end{array}$ & $\begin{array}{l}1993- \\
2028\end{array}$ & 240 ha & $\begin{array}{l}\text { housing + } \\
\text { services + in- } \\
\text { dustry / under } \\
\text { construction / }\end{array}$ & $\begin{array}{l}\text { neomodern- } \\
\text { ism }\end{array}$ & very good & acceptance & good \\
\hline $\begin{array}{l}\text { Wilanów } \\
\text { Warszawa }\end{array}$ & $2002-$ & 160 ha & $\begin{array}{l}\text { housing }+ \\
\text { services / in } \\
\text { progress / }\end{array}$ & $\begin{array}{l}\text { neomodern- } \\
\text { ism }\end{array}$ & good & $\begin{array}{l}\text { partial accep- } \\
\text { tance }\end{array}$ & sufficient \\
\hline $\begin{array}{l}\text { Konstantynów } \\
\text { Łódzki }\end{array}$ & $\begin{array}{l}2010- \\
2020\end{array}$ & 2 ha & residential & $\begin{array}{l}\text { traditional } \\
\text { modernism }\end{array}$ & good & $\begin{array}{l}\text { partial accep- } \\
\text { tance }\end{array}$ & sufficient \\
\hline $\begin{array}{l}\text { Żerniki } \\
\text { Wrocław }\end{array}$ & $2013-$ & $\begin{array}{l}10 \text { ha } \\
1 \text { st } \\
\text { stage } \\
\text { About } \\
50 \text { ha ul- } \\
\text { timately }\end{array}$ & $\begin{array}{l}\text { housing }+ \\
\text { services / in } \\
\text { progress / }\end{array}$ & $\begin{array}{l}\text { neomodern- } \\
\text { ism }\end{array}$ & very good & $\begin{array}{l}\text { partial accep- } \\
\text { tance }\end{array}$ & good \\
\hline
\end{tabular}

- przeciwdziałanie wykluczeniu społecznemu

- vekologia, minimalizacja wydatków eksploatacyjnych

- voptymalizacja komunikacji - współdziałanie z systemem komunikacji miejskiej

- vnowe formy organizacji budownictwa

- vudział społeczeństwa

ZAŁOŻENIA FUNKCJONALNE, ARCHITEKTONICZNE:

- przestrzenie prywatne, półprywatne, półpubliczne, publiczne

- optymalizacja struktury mieszkań

- lokalne tradycje materiałowe i wykonawcze

- miejsce pracy: małe powierzchnie adresowane dla działalności zawodowej

- technologie zintegrowanego projektowania

- różne formy domów mieszkalnych: duże budynki mieszkalne ,małe domy wielorodzinne, wille miejskie: próba stworzenia domu modelowego

Skala i układ zabudowy umożliwia tworzenie małych jednostek sąsiedzkich skupionych w obrębie fragmentu osiedla. Powstaną duże budynki wielorodzinne oraz kameralne jednostki złożone z kilku mieszkań i domy jednorodzinne szeregowe i wolnostojące. Umożliwi to zaangażowanie różnych inwestorów i deweloperów, ma-
- integrated design technologies

- various forms of residential houses: large residential buildings, small multi-family houses, city villas: an attempt to create a model house

The scale and layout of buildings allows for the creation of small neighborhood units concentrated within a fragment of the estate. Large multi-family buildings and intimate units consisting of several apartments as well as single-family terraced and detached houses will be erected. This will enable the involvement of various investors and developers, small cooperatives, and individual investors. Architects want to design housing estates which structure will facilitate the creation of local communities. Common spaces have been designed in such a way as to create a clear grade system. Intimate spaces between buildings intended for neighborly groups of users as spaces with a semi-public function. Private space zones adjacent to the apartments have been separated. There are no fences as it has been assumed that security will be provided by a sense of belonging to a place. Żerniki is a green housing estate. The 
łych spółdzielni, kooperatyw, czy inwestorów indywidualnych. Architekci chcą zaprojektować osiedla, których struktura ułatwiać będzie tworzenie lokalnych wspólnot. Przestrzenie wspólne zostały zaprojektowane w taki sposób, aby stworzyć czytelną ich gradację. Kameralne przestrzenie między budynkami przeznaczone dla sąsiedzkich grup użytkowników jako przestrzenie o funkcji półpublicznej. Wydzielono strefy przestrzeni prywatnej przylegającej bezpośrednio do mieszkań. Zespoły nie są grodzone, ponieważ przyjęto że bezpieczeństwo zapewni poczucie przynależności do miejsca. Żerniki to osiedle zielone. Projekt, zarówno pod względem jego skali, układu funkcjonalnego jak i architektury oraz planowanych rozwiązań technologicznych, został pomyślany w taki sposób, aby osiedle spełniało najsurowsze normy ekologiczne, a jego przyszła eksploatacja była możliwie najtańsza. W XXI wieku dominować będą inteligentne miasta a Żerniki stanowią o rozsądnej myśli zarządzających Wrocławiem. Budowanie Smart City to realizacja dzieła międzywojennego. W 1929 roku wzniesiono osiedle wzorcowe w ramach realizacji programu WUWA. Teren osiedla podzielono na sektory dając mnóstwo terenów na ciąg dalszy eksperymentu. Wraz z uruchamianiem kolejnych komponentów dzielnicy rośnie popyt na kupno tutaj mieszkania. Sprowadzają się tu zasobni pracownicy korporacji, technolodzy, architekci, finansjera. Nowa wrocławska elita. Nawet krytycy osiedla muszą przyznają, że jak na polskie realia Nowe Żerniki wyróżniają się wśród krajowych inwestycji. Poligon bezcennej wiedzy i owocnych obserwacji, jak tworzyć nowe przestrzenie inspirując się sprawdzonymi przykładami z zewnątrz, jak i dokonaniami przeszłości. Społeczność rezygnując z pewnej części prywatności docenia sąsiedzkie współżycie. Smart znaczy bliżej mieszkańca, mniej technologii, więcej współdziałania. Fakt, że to wrocławskie osiedle określono mianem WuWA2, świadczy o uznaniu jakim cieszy się ta realizacja. Osiedle rośnie stopniowo. Kilka szczytnych pomysłów musiano jednak porzucić. Nie udało się wyeliminować samochodów, na obrzeżach osiedla dopuszczono możliwość parkowania. Nie wszystkie wspólne przestrzenie przyjęły się w równym stopniu dobrze. Jednak ten śmiały projekt będzie stanowił bardzo dobry przykład łączenia przestrzeni - architektury wraz ze szczególnym poszanowaniem terenów zielonych. Terenów w ramach dziedzińców i otwartych, dla rekreacji i zdrowia mieszkańców.

\section{Podsumowanie}

Konkludując należy zwrócić uwagę, że większość z przedstawionych i kategoryzowanych zespołów zabudowy jest projektowana jako marzenie choćby częściowego powrotu do miasta ogrodu. To szczególnie jak w idealnym mieście: brak ogrodzeń, miasto otwarte, idee miasta szytego na miarę, wykorzystanie źródeł naturalnych - środowisko, wpisanie w otoczenie, miasto przyjazne, zjawisko Smart City. Podobne sugestie płyną z polityk prezentowanych przez ACE. Tutaj oprócz walki o dobre, długożyjące budynki i próbę budowania idealnej struktury społecznej, co jest utopią, mamy ważny element zwracający uwagę na konieczność uwzględniania wartości społecznej, środowiskowej i ekonomicznej. Kolejną wyjątkowo ważną polityką jest poszanowanie przyrody. project, both in terms of its scale, functional layout and architecture, as well as planned technological solutions, was designed in such a way that it meets the strictest ecological standards and its future operation is as cheap as possible. Smart cities will dominate in the 21 st century, so Wrocław is building its Smart City district. It was similar here in 1929, where a model housing estate was built as part of the WUWA program. There are plenty of areas around for the continuation of the experiment. If it works. Or maybe it will work, because as the next components of the district are launched, the demand for buying an apartment here is growing. Wealthy corporate employees, technologists, architects and financiers come here. The new Wrocław elite. Even critics of the estate must admit that, considering the Polish realities, Nowe Żerniki stand out among domestic investments.(Fig.6) A training ground for invaluable knowledge and fruitful observations on how to create new spaces inspired by proven examples from the outside, as well as past achievements. The emerging community, giving up some privacy, appreciates neighborly coexistence in the Scandinavian style. Smart means closer to the inhabitant, less technology, more interaction. The fact that it was the district of Wrocław that was baptized as WuWA2 proves the reputation of this concept. The housing estate is growing gradually. Several noble ideas had to be curtailed. It was not possible to completely eliminate cars, parking is allowed on the outskirts of the estate. Not all common spaces were equally well received. However, this bold project will be a very good example of combining space - architecture with respect for green areas.

\section{Summary}

Concluding the presented and categorized complexes, it should be noted that most of them are designed as a dream to return to the garden city, at least partially. It is especially like in an ideal city: no fences, an open city, ideas of a tailor-made city, the use of natural resources - the environment, a part of the surroundings, a friendly city, the Smart City phenomenon. Similar suggestions come from the policies presented by the ACE. Here, in addition to fighting for decent, long-lived buildings and trying to build an ideal social structure, which is a utopia, we have an important element that highlights the need to take into account social, environmental and economic values. Another extremely important policy is to respect nature. Here are some of the most relevant policies in the next White Book of Architects of Europe: "Summary of ACE positions developed by the Environment Sutainable Architecture Workgroup since 2013 08/14/2020 Most people in the EU spend around $90 \%$ of their time in buildings and $100 \%$ in the built environment. Buildings shape social and cultural structures and influence human health, well-being and productivity. Buildings are 
Oto kilka najistotniejszych polityk zawartych w kolejnej Białej Księdze Architektów Europy: Podsumowanie stanowisk ACE opracowanych przez grupę roboczą Environment Sutainable Architecture Workgroup od 2013 roku 14.08.2020 Większość Iudzi w UE spędza około 90\% swojego czasu w budynkach i $100 \%$ w środowisku zabudowanym. Budynki kształtują konstrukcje społeczne i kulturowe oraz wpływają na zdrowie, dobrostan i produktywność ludzi. Budynki odpowiadają również za ponad $40 \%$ emisji dwutlenku węgla w UE, podczas gdy połowa wszystkich surowców i jedna trzecia wszystkich odpadów w UE jest związana z budownictwem. Duża część tego jest określana podczas projektowania i konieczne jest, aby architekci byli uprawnieni do poprawy procesu podejmowania decyzji w sektorze. Rozwiązanie problemu zagrożenia klimatycznego i biosfery wymaga pilnych działań w celu ustanowienia ram finansowych, regulacyjnych i badawczych, które: -Uzupełnia informacje zwrotne i walidacje osiągniętych wyników w praktyce, aby przyspieszyć innowacje i ułatwić rozliczanie się z jakości i wydajności; - Łagodzi wpływ i promuje korzyści w całym okresie eksploatacji budynków i komponentów, aby zapewnić, że wpływ cyklu życia może być w pełni uwzględniony z góry; -Uznaje, że tworzenie wartości społecznej, ekonomicznej i środowiskowej ma fundamentalne znaczenie dla osiągnięcia radykalnej zmiany wyników budynków w UE. (ACE, Communication of the EU Commission, An SME Strategy for a sustainable and digital Europe LAutorzy mają nadzieję, że po opisaniu i waloryzacji przykładów z całej Europy będą mogli w dalszych pracach badawczych nad strukturami mieszkalnymi uzyskać bardzo obiektywny obraz tendencji w realizowanych zespołach czy miasteczkach mieszkalnych.

\section{LITERATURA:}

[1] Pokluda, Z., 2009, Old and New Zlín: The Transformation of a City, The Bata Phenomenon: Zlín Architecture 1910-1960.

[2] Redzinska, K., \& Jedraszko-Macukow, M., 2013, Osiedla" Aspern Seestadt" w Wiedniu i" Miasteczko Wilanów" w Warszawie w świetle idei zielonej infrastruktury. Problemy Ekologii Krajobrazu, 36, s. 73-84.

[3] Tatarkiewicz, W., (1982). Dzieje sześciu pojęć: Sztuka, piękno, forma, twórczość, odtwórczość, przeżycie estetyczne. Wyd. 3. Warszawa: Państwowe Wydawnictwo Naukowe.

[4] Samorząd Miasta Łodzi, 1938, Sprawozdanie z działalności Zarządu Miejskiego w latach 1933-1937, dostępny w: https://fbc.pionier.net.pl/search $\# \mathrm{q}=\mathrm{dc}$ description $\% 3$ A $\% 22$ Tyt.ok\% C5 $\% 82 . \% 3$ A $\% 20$ Samorz $\%$ C4\% 85 d $\% 2 \overrightarrow{0}$ Miasta\%20\%C5\%81 odzi\%20w\%20latach\%201933-1937.\%20Sprawozdanie $\% 20$ \% 20dzia\%C5\%82alno\%C5\%9Bci\%20Zarz\%C4\%85du\%20Miejskiego\%20w\%20\%C5\%81 odzi.\%20Rok\%20wyd.\%201938.\%22), dostęp: 10 022021.

\section{ŹRÓDŁA INTERNETOWE:}

[1] Sady Żoliborskie kolonia I - Powojenny Modernizm [online], http://cargocollective.com. [Dostęp 20.04.2021]. Dostępny w: http://cargocollective.com/ powojennymodernizm/Sady-Zoliborskie-kolonia-I.

[2] Plan osiedla - Nowe Żerniki (WUWA2) - Wrocław - oficjalny serwis modelowego osiedla [online]. Nowe Żerniki (WUWA2) | Oficjalny serwis modelowego osiedla. [Dostęp 20.04.2021]. Dostępny w: https://nowezerniki.pl/idea/ plan-osiedla/

[3] Communication of the EU Commission, An SME Strategy for a sustainable and digital Europe, [online], https://www.ace-cae.eu/ [Dostęp 20.04.2021]. Dostępny w: https://www.ace-cae.eu/services/news/?tx ttnews \%5BbackPid\%5D=18tx_ttnews \%5Btt_news \%5D =2151\&cHash=aca e2bfd0fd174d95c3a938f5e60e-489

\section{INNE DOKUMENTY:}

[1] Ratusz w Wiedniu( marzec 2004) folder informacyjny z ankietą skierowaną do mieszkańców Wiednia - ogólna propozycja programowa dotycząca ich oczekiwań. also responsible for more than $40 \%$ of the EU's carbon dioxide emissions, while half of all raw materials and a third of all waste in the EU are related to construction. Much of this is determined during design and it is imperative that architects have the authority to improve decision making in the sector. Addressing the climate and biosphere threat requires urgent action to establish a financial, regulatory and research framework that: - Complements feedback and practical validation of results achieved to accelerate innovation and facilitate accountability for quality and efficiency; - Mitigates impacts and promotes benefits over the lifetime of buildings and components to ensure that lifecycle impacts can be fully planned; -Recognizes that creating social, economic and environmental value is fundamental to radically changing the performance of buildings in the EU". (ACE, Communication of the EU Commission, An SME Strategy for a sustainable and digital Europe). The authors hope that, after describing and evaluating examples from all over Europe, they will be able to obtain a very objective picture of trends in the implemented residential complexes or towns in further research on residential structures.

\section{REFERENCES:}

[1] Pokluda, Z., 2009, Old and New Zlín: The Transformation of a City, The Bata Phenomenon: Zlín Architecture 1910-1960. [2] Redzinska, K., \& Jedraszko-Macukow, M., 2013, Osiedla" Aspern Seestadt" w Wiedniu i" Miasteczko Wilanów" w Warszawie w świetle idei zielonej infrastruktury. Problemy Ekologii Krajobrazu, 36, s. 73-84.

[3] Tatarkiewicz, W., (1982). Dzieje sześciu pojęć: Sztuka, piękno, forma, twórczość, odtwórczość, przeżycie estetyczne. Wyd. 3. Warszawa: Państwowe Wydawnictwo Naukowe.

[4] Samorzad Miasta Łodzi, 1938, Sprawozdanie z działalności Zarządu Miejskiego w latach 1933-1937, dostępny w: https:// fbc. pionier.net.pl/search\#q=dc_description $\% 3 \mathrm{~A}(\% 22 \mathrm{Tyt}$. ok\% C5\% 82. \%3A\%20Samorz\%C4\%85d\%20Miasta\%20 \%C5\%81odzi\%20w\%20latach\%201933-1937.\%20Sprawozdanie $\% 20$ z $\% 20$ dzia \% C5\% 82 alno \% C5\% 9B ci \% 20 Zarz\%C4\%85du\%20Miejskiego\%20w\%20\%C5\%81 odzi.\%20 Rok\%20wyd.\%201938.\%22), dostęp: 10022021

\section{INTERNET SOURCES:}

[1] Sady Żoliborskie kolonia I - Powojenny Modernizm [online] http://cargocollective.com. [Dostęp 20.04.2021]. Dostępny w: http://cargocollective.com/powojennymodernizm/Sady-Zoliborskie-kolonia-I.

[2] Plan osiedla - Nowe Żerniki (WUWA2) - Wrocław - official website of the model estate [online]. Nowe Żerniki (WUWA2) | Official website of the model estate. [Access: 20.04.2021]. Dostepny w: https://nowezerniki.pl/idea/plan-osiedla/

[3] Communication of the EU Commission, An SME Strategy for a sustainable and digital Europe, [online], https://www.ace-cae.eu/ [Dostęp 20.04.2021]. Accessed in: https://www.ace-cae.eu/services/news/?tx ttnews \%5BbackPid\%5D=1\&tx ttnews \%5Btt_news $\% 5 \mathrm{D}=\overline{2} 151 \mathrm{dcHash}=$ acae2bfd0fd174d95 c3a938f5e60e-489

\section{OTHER DOCUMENTS:}

[1] Vienna City Hall (march 2004)information folder with a questionnaire addressed to the inhabitants of Vienna - a general program proposal regarding their expectations. 